\title{
Article \\ Effect of Alloying Additives and Microadditives on Hardenability Increase Caused by Action of Boron
}

\author{
Beata Białobrzeska
}

check for

updates

Citation: Białobrzeska, B. Effect of Alloying Additives and Microadditives on Hardenability Increase Caused by Action of Boron. Metals 2021, 11, 589. https://doi.org/10.3390/met11040589

Academic Editor: Mariusz Król

Received: 26 February 2021

Accepted: 1 April 2021

Published: 4 April 202

Publisher's Note: MDPI stays neutral with regard to jurisdictional claims in published maps and institutional affiliations.

Copyright: (C) 2021 by the author. Licensee MDPI, Basel, Switzerland. This article is an open access article distributed under the terms and conditions of the Creative Commons Attribution (CC BY) license (https:// creativecommons.org/licenses/by/ $4.0 /)$.
Department of Vehicle Engineering, Faculty of Mechanical Engineering, Wrocław University of Science and Technology, Wybrzeże Wyspiańskiego 27, 50-370 Wrocław, Poland; beata.bialobrzeska@pwr.edu.pl

\begin{abstract}
The presented work was aimed at evaluating influence of boron on hardenability of steel quantitatively and evaluating this effect during complex use of boron with other alloying additives like chromium, vanadium and titanium. For this purpose, eight melts with variable chemical compositions were prepared. From the ingots, cylindrical specimens with normalized dimensions according to EN ISO 642:1999 were cut out and subjected to full annealing at $1200{ }^{\circ} \mathrm{C}$ and to normalizing at $900^{\circ} \mathrm{C}$. Such specimens were subjected to the hardenability Jominy test. In order to distinguish the influence of boron on hardenability of a given melt and thus to eliminate the differences resulting from its chemical composition, grain size and austenitizing temperature, the obtained ideal critical diameter was corrected and the boron effectiveness factor was determined. The performed examinations and analyses showed that inadequate quantities of microadditives result in losing the benefits coming from introduction of boron as the hardenability-improving element and can even result in a reduction of hardenability of the boron-containing steel.
\end{abstract}

Keywords: boron; hardenability; Jominy; heat treatment; low-alloy steels

\section{Introduction}

In Europe, low-alloy steels with additions of boron were produced for the first time in 1970 by the Swedish metallurgical concern SSAB Oxelösund [1] as steels with higher abrasive-wear resistance. Metallurgy in Sweden has the centuries-old tradition. As early as in the 17th century, Sweden delivered about a half of total European production of steel. That resulted from both deposits of especially pure iron ore and availability of timber from that charcoal for iron smelting was obtained. In turn, the boron steel 22MnB5, which is characterized by a simple chemical composition and basically only manganese in alloy content in addition to boron, is also successfully used in the automotive industry [2-5]. The present-day micro- and low-alloy steels containing boron, produced by advanced manufacturing technologies, have very good mechanical properties at moderate prices and their properties are decided by their structures obtained after a specific heat- or thermoplastic treatment. Based on advertising information for boron steels, it can generally be concluded that a significant proportion of commercially offered steels have tensile strengths in excess of $1500 \mathrm{MPa}$ but in many cases, the strength of $2000 \mathrm{MPa}$ is also exceeded [6].

However, the history of using boron as an alloying additive to steel began much earlier. It was found as early as the 1930s that an additive of boron significantly increased hardenability of low- and medium-carbon steels. As a result, a group of weldable bainitic steels was obtained, with their tensile strength ranging from 530-1200 MPa. In the subsequent years, this element was more and more widely applied to replace other expensive alloying elements like nickel, molybdenum and chromium, when wars significantly restricted their availability [7]. Increase of steel hardenability is obtained by small contents of boron, trace amounts for other elements. Influence of boron on hardenability of steel was analyzed in [8-12]. Maximum increase of hardenability is already observed after adding as little as 10-30 wt. ppm. of boron but majority of reviews recommend boron contents in a range 
between 5-20 wt. ppm. [12]. A hardenability increase was found by boron additions of only 5 wt. ppm in low-alloyed $\mathrm{Cr}$ steels that could be used as a substitute for the costlier CrNiMo-steels for high-strength automotive parts [9]. The amount of boron higher than the solubility limit of $6 \mathrm{wt}$. ppm of B in austenite does not further improve hardenability. When the soluble boron is fully effective, maximum toughness can also be observed. Soluble boron contents less than $4 \mathrm{wt}$. ppm lead to an inhomogeneous hardenability along the cross section and, as a result, to stronger distortion [13]. This can explained by the fact that at higher boron contents, the solubility of $\mathrm{B}$ is exceeded and coarse borocarbides such as $\mathrm{M}_{23}(\mathrm{~B}, \mathrm{C})_{6}$ or coarse $\mathrm{BN}$ form along GBs which promote the ferrite nucleation $[10,11,14,15]$. If added in too large amount, boron also creates with iron the compound $\mathrm{Fe}_{2} \mathrm{~B}$ whose particles become nuclei, facilitating the diffusive transformation and, as a result, hardenability decreases. Moreover, effectivity of boron in steel depends on its form and thus it is strictly related to chemical composition and metallurgical purity of steel, especially with contents of carbon and nitrogen [16]. Boron shows high affinity for oxygen and nitrogen and this is why the alloying elements like titanium and aluminum are introduced to steel. Boron acts effectively when is dissolved in solid solution, but thanks to its high diffusion rate it is accumulated on grain boundaries reducing their energy and on all defects that facilitate nucleation. This impedes nucleation and the transition start lines are shifted towards longer times [17]. Moreover, the effect of boron is observed up to a carbon concentration of $0.53 \%$ only, so boron as the hardenability improving element is applied in low- and medium-carbon steels only. In steels containing $0.4 \% \mathrm{C}$, boron additions can double the hardenability compared with the base composition without boron [12]. Boron is mostly used in low-alloy steels, but some reports can be found in literature saying that an addition of boron also increases hardenability of carbon steels. For example, Llewellyn and Cook [9] observed an increase in hardenability caused by the addition of boron in carbon steels up to a carbon content of $0.53 \%$.

The issue concerning influence of boron on hardenability of steel is a complex one. This is evidenced even by the way the ideal critical diameter is determined according to ASTM A 255-20a. In the case of steels containing microadditives of boron, the $B F$ factor (boron factor) is determined first:

$$
B F=\frac{D_{I J}}{D_{I}}
$$

where: $D_{I J}=$ ideal diameter read-out from the tables for the distance from the Jominy specimen end face corresponding to $50 \%$ of martensite in steel with the given carbon content; $D_{I}=$ ideal diameter calculated from the equation (2).

$$
D_{I}=D_{I C} \cdot f_{i}
$$

where: $D_{I C}=$ ideal critical diameter for the Fe-C alloy with carbon concentration of $0.7 \%$ and primary austenite grain size $\mathrm{N}=7$ acc. to ASTM read-out from the tables; $f_{i}=$ hardenability factors of individual alloying elements with the values depending on their concentrations.

Next, the alloy factor $A F$ is calculated for the steel:

$$
A F=\frac{D_{I}}{f_{C}}
$$

where: $f_{C}=$ carbon hardenability factor for the given concentration of carbon in the steel.

Ideal critical diameter for the boron-containing steel $D_{I B}$ is calculated from the formula:

$$
D_{I B}=D_{I} \cdot f_{B}
$$

where: $f_{B}=$ boron hardenability factor read-out from the tables for the calculated value $A F$ (3) and the given carbon concentration.

An increase of hardness can also be obtained by connecting the additive of boron with additives of other elements like chromium, molybdenum, manganese and niobium. 
In literature [8], the information can be found that vanadium even to $0.085 \%$ does not influence effectiveness of boron. This is especially interesting, since vanadium, beside titanium and niobium, is one of the microadditives introduced together with boron to micro- and low-alloy low-carbon steels [18]. In general, there are little data in the literature concerning influence of microadditives on hardenability increase related to an addition of boron, or such data are incomplete [8,19-26]. In particular, a lot of research work has been devoted to analyzing the effect of complexly added molybdenum and boron on hardenability. The effectiveness of molybdenum in increasing the hardenability increases with the presence of boron. In the absence of boron, molybdenum is only half as effective in improving steel hardenability [19]. The introduction of $0.002 \%$ B into molybdenum steel causes an inhibition of the austenite-ferrite transformation [20], and at a content of $0.58 \%$ molybdenum and $0.005 \%$ titanium an increase in boron microadditivity from 0.002 $0.007 \%$ can double hardenability [21]. Another beneficial effect of boron microadditive with the addition of $0.016 \%$ Mo was also the lowering of the start temperature of the bainitic transformation for 1021B steel, as this reduces the share of upper bainite, which will have a further beneficial effect on the mechanical properties of the steel [22]. In turn, elements such as niobium, vanadium [8] and titanium [23] can increase the hardenability of austenitized steel, especially at higher temperatures. What is more, in the research of Briedis and Cuddy [24], where the effect of simultaneous addition of boron, titanium and vanadium on the hardenability of steels containing $0.4 \% \mathrm{C}, 1 \% \mathrm{Mn}$ and $0.7 \% \mathrm{Cr}$ was studied, the authors specifically indicated what percentage of the individual components most enhances the effect of boron on hardenability. The highest hardenability among the group of analyzed melts was obtained with a complex containing $0.047 \% \mathrm{Ti}, 0.053 \%$ $\mathrm{V}$ and $0.008 \% \mathrm{~B}$. Also in the presence of manganese, an element found in steels for hotstamping, an increase in hardenability caused by boron addition, was observed [25], while Grande [26] demonstrated that even phosphorous operates via a similar mechanism of segregating to austenite GBs together with boron inhibits the nucleation of hypoeutectoid ferrite. Therefore, quantitative evaluation of influence of boron on hardenability of steel, and in particular analysis of influences of other alloying additives on the effect of boron, is extremely important. The purpose of this work is to evaluate the effect of boron on hardenability of steel quantitatively and to assess this effect in the case when boron is applied together with other alloying elements like chromium, vanadium and titanium.

\section{Materials and Methods}

The material for the research consisted of 8 melts with various chemical compositions, prepared in the Foundry Research Institute in Krakow, Poland. Molds were made of bentonite molding compound using wooden patterns of the agreed shape. The melts with determined chemical compositions were prepared in an induction medium frequency furnace Radyne $100 \mathrm{~kW}$ with capacity $120 \mathrm{~kg}$ (Radyne Corporation, Milwaukee, WI, USA), equipped with neutral lining. Each time, mass of charge was ca. $110 \mathrm{~kg}$. Over the crucible, a kind of hood was installed, where argon gas was blown-in to maintain the assumed chemical composition. A charge consisted of ARMCO iron, scrap of low-carbon steel, alloying additives FeMn 80, FeCr 60, Mn, and a carbonizer. Depending on the selected chemical composition, the following materials were also added: FeB 8, FeTi 25, FeV 70, Al, and Ti. When the charge was molten and the melt reached the set temperature, a sample was taken for chemical analysis. If necessary, chemical composition was corrected and the components that could burn-out were added just before casting. The molten metal was poured to a preheated ladle, temperature was measured and a sample was taken for final chemical analysis. The temperature of pouring the molds was $1540{ }^{\circ} \mathrm{C}$. After cooling-down and cleaning, sprues were removed from the ingots. Ultrasound inspections made with use of a defectoscope CUD 9900 No. 04002 (Ultra, Wrocław, Poland) showed no disqualifying defects in the examined ingots.

Chemical composition of the ingots was analyzed with a spark-trigger optical emission spectrometer ARL NA (Thermo Fisher Scientific, Waltham, MA, USA), except concentration 
of boron and other minimum-quantity elements that were determined with an atomic absorption spectrometer Solaar M6 Thermo (Thermo Fisher Scientific, Waltham, MA, USA) or with a glow discharge spectrometer GDS-500 A Leco (Leco Corporation, St. Joseph, MI, USA). The melts used in the research differed in concentrations of boron, chromium, vanadium and titanium, which made it possible to examine effectiveness of individual or complex microadditives for boron-related hardenability. Concentrations higher than the limit alloying values were as follows: boron in melts 1,3,5 and 7, chromium in melts 3, 4, 5, 6, 7 and 8; vanadium in melts 5 and 6; titanium in melt 8 (see Table 1).

Table 1. Chemical composition of analyzed melts.

\begin{tabular}{|c|c|c|c|c|c|c|c|}
\hline Melt No. & $C(w t \%)$ & Si $(w t \%)$ & $\operatorname{Mn}(w t \%)$ & $P(w t \%)$ & $S(w t \%)$ & $\mathrm{Cr}(w t \%)$ & $\mathrm{Ni}(w t \%)$ \\
\hline 1 & 0.31 & 0.34 & 0.30 & 0.018 & 0.010 & 0.027 & 0.044 \\
\hline 2 & 0.34 & 0.37 & 0.59 & 0.016 & 0.010 & 0.030 & 0.060 \\
\hline 3 & 0.41 & 0.43 & 1.32 & 0.023 & 0.011 & 0.900 & 0.091 \\
\hline 4 & 0.36 & 0.38 & 1.34 & 0.018 & 0.011 & 0.850 & 0.070 \\
\hline 5 & 0.38 & 0.47 & 1.37 & 0.018 & 0.011 & 0.990 & 0.060 \\
\hline 6 & 0.37 & 0.45 & 1.40 & 0.017 & 0.009 & 0.970 & 0.075 \\
\hline 7 & 0.38 & 0.41 & 1.40 & 0.018 & 0.010 & 0.900 & 0.100 \\
\hline 8 & 0.30 & 0.41 & 1.45 & 0.017 & 0.010 & 1000 & 0.112 \\
\hline Melt No. & Mo (wt $\%)$ & $\mathrm{Cu}(w t \%)$ & $V(w t \%)$ & $\mathrm{Ti}(w t \%)$ & Al (wt $\%)$ & B (wt \%) & $\mathrm{N}$ (ppm) \\
\hline 1 & 0.015 & 0.047 & 0.002 & 0.002 & 0.025 & 0.002 & 121 \\
\hline 2 & 0.013 & 0.073 & 0.006 & 0.002 & 0.022 & - & 115 \\
\hline 3 & 0.024 & 0.100 & 0.010 & 0.005 & 0.024 & 0.003 & 192 \\
\hline 4 & 0.020 & 0.070 & 0.009 & 0.004 & 0.026 & - & 62 \\
\hline 5 & 0.017 & 0.043 & 0.260 & 0.006 & 0.023 & 0.003 & 184 \\
\hline 6 & 0.020 & 0.060 & 0.275 & 0.013 & 0.022 & - & 62 \\
\hline 7 & 0.030 & 0.110 & 0.010 & 0.019 & 0.022 & 0.003 & 165 \\
\hline 8 & 0.029 & 0.110 & 0.013 & 0.059 & 0.039 & - & 161 \\
\hline
\end{tabular}

Cylindrical specimens with standardized dimensions acc. to EN ISO 642:1999 were taken from the ingots, subjected to full annealing at $1200{ }^{\circ} \mathrm{C}$ and next normalized at $900{ }^{\circ} \mathrm{C}$ for $1 \mathrm{~h}$. Then, the specimens were austenitized for $30 \mathrm{~min}$ at the temperatures specified in Table 2. Austenitization temperatures were selected after dilatometric examinations with use of a dilatometer Linseis L78 R.I.T.A (Linseis Messgeräte $\mathrm{GmbH}$, Selb, Germany), where the Ac3 temperatures were determined. The austenitization temperature was $50{ }^{\circ} \mathrm{C}$ higher than the $\mathrm{A}_{\mathrm{c} 3}$ temperature.

Table 2. Austenitizing temperatures of individual melts.

\begin{tabular}{ccccccccc}
\hline \multirow{2}{*}{$\mathrm{T}_{\mathrm{A}}\left({ }^{\circ} \mathrm{C}\right)$} & Melt 1 & Melt 2 & Melt 3 & Melt 4 & Melt 5 & Melt 6 & Melt 7 & Melt 8 \\
\cline { 2 - 9 } & 890 & 870 & 830 & 840 & 840 & 870 & 810 & 890 \\
\hline
\end{tabular}

The described heat treatment was carried-out under a protective atmosphere of argon in a conventional furnace FCF 12 SHM/R (Czylok, Jastrzębie-Zdrój, Poland) with a gastight retort. Next, the specimens were subjected to end quenching on a device according to EN ISO 642:1999. After the end-quench test was performed on each specimen, two material layers parallel to the specimen axis were milled to the depth of $0.4 \mathrm{~mm}$. On the prepared surfaces, Rockwell hardness was measured and average hardness values at the same distances from the specimen face were calculated. The distances from the specimen face were according to the instructions for the Jominy test (EN ISO 642:1999). Then, hardness curves were plotted to show relationships between hardness and distance from the specimen end face. On the hardenability curve HRC $=\mathrm{f}(\mathrm{l})$, hardness of the semi-martensitic zone was marked, so that the distance $J$ between this zone and the specimen end face could be determined. Hardness of the semi-martensitic zone for a specific carbon concentration was read-out from the empirical curves published by Hodge 
and Orechoski [27]. On the grounds of the found J values, the ideal critical diameter $D_{I J}$ were determined using the Grossman nomograph [28] and ASTM A 255-02 Standard.

In order to distinguish the effect of boron on hardenability of the given melt and thus to eliminate the differences resulting from chemical composition, grain size and austenitizing temperature, the obtained ideal critical diameter had to be corrected [29-31]. This correction was carried-out in the following steps:

Using the Jackson's and Christenson's data [32], the $J$ value obtained for the given austenitization temperature was corrected to the value corresponding to the austenitization temperature of the basic melt. The relation between the correction factor $f_{\text {corr }}$ and the austenitization temperature $T$ is given by the formula:

$$
f_{\text {corr }}=6.4217+3.78 \cdot 10^{-3} \mathrm{~T}-0.2964 \mathrm{~T}^{2}
$$

The corrected distance $J_{\mathcal{C}}$ between the semi-martensitic zone and the specimen end face is calculated from the formula:

$$
J_{c}=J \cdot \frac{f_{\text {corr }}\left(T_{b}\right)}{f_{\text {corr }}(T)}
$$

where: $T_{b}=$ austenitization temperature of the basic melt in ${ }^{\circ} \mathrm{C}, T=$ austenitization temperature of the analyzed melt in ${ }^{\circ} \mathrm{C}$. On the ground of the corrected location of the semimartensitic zone $J_{c}$, the corrected ideal critical diameter $D_{\text {IJcorr }}$ was determined from the Grossman nomograph and ASTM A 255-02 Standard.

Using the Grossmann's analytical method, influence of differences in concentrations of conventional alloying elements and influence of grain size were corrected. The ideal critical diameter $D_{I J c}$ was corrected according to the formula:

$$
D_{I J c o r r}=D_{I J c} \cdot \frac{D_{I C b} \cdot f_{M n b} \cdot f_{S i b} \cdot f_{M o b} \cdot f_{C r b} \cdot f_{N i b}}{D_{I C} \cdot f_{M n} \cdot f_{S i} \cdot f_{M o} \cdot f_{C r} \cdot f_{N i}}
$$

where: $D_{I C}, D_{I C b}=$ basic ideal critical diameter dependent on grain size and carbon concentrations in the basic melt and the analyzed melt:

$$
D_{\text {IC }}=k \sqrt{C}
$$

where: $k=$ constant dependent on grain size number acc. to Moser and Legat [33], C $=$ carbon concentration in $\mathrm{wt} \%, f_{i}$ and $f_{i b}=$ hardenability factors for individual alloying elements except carbon in the basic melt and the analyzed melt, calculated from the formula:

$$
f_{i}=B_{i}{ }^{\%} M_{i}
$$

where: $B_{i}=$ characteristic coefficient for a given alloying element according to Table $3, M_{i}=$ exponent equal to percent concentration of this element.

Table 3. Coefficient $B$ values determining influence of main alloying elements on hardenability according to Moser and Legat.

\begin{tabular}{cc}
\hline Alloying Element & Coefficient $\boldsymbol{B}$ \\
\hline $\mathrm{Mo}$ & 3275 \\
$\mathrm{Mn}$ & 2210 \\
$\mathrm{Cr}$ & 2130 \\
$\mathrm{Si}$ & 1400 \\
$\mathrm{Ni}$ & 1470 \\
\hline
\end{tabular}


The effect of boron on hardenability was evaluated using the factor $f_{2}$, calculated as follows:

$$
f_{2}=\frac{D_{I J c o r r}}{D_{I J b}}
$$

This effect was evaluated by comparing the melts in pairs, while the basic melt was that free of boron: Melts 1 and 2 (basic melt 2), melts 3 and 4 (basic melt 4), melts 5 and 6 (basic melt 6), melts 7 and 8 (basic melt 8).

In addition, microstructure examinations were carried-out after normalizing and after quench hardening, as well as grain size analysis after hardening. Microscopic observations were performed using a light microscope Nikon ECLIPSE MA200 (Nikon Corporation, Tokyo, Japan). Microstructures after normalizing and after quench hardening were revealed by etching with the reagent $74\left(5 \% \mathrm{HNO}_{3}\right.$ solution in alcohol) acc. to ASTM E407. To reveal boundaries of former austenite grains, the prepared metallographic sections were etched with the reagent 81 ( $2 \mathrm{~g}$ of picric acid, $1 \mathrm{~g}$ of sodium tridecylbeznzene sulfonate and $100 \mathrm{~mL} \mathrm{H}_{2} \mathrm{O}$ ) acc. to ASTM E407, at ca. $55^{\circ} \mathrm{C}$. Former austenite grain size in representative areas was determined quantitatively with use of the program Image (version 1.52a, National Institute of Mental Health, Bethesda, MD, USA). To that end, cross-section areas (a) of 100 randomly selected grains were determined by the planimetric method and then diameter $(d)$ of a plain grain was determined as $\sqrt{a}$. The results were analyzed with the program Statistica (version 13.1, StatSoft, Tulsa, OK, USA) to obtain distributions of grain diameters, for the constant number of 12 classes. The obtained empirical distributions were analyzed for conformity with the theoretical distributions: log-normal, exponential and gamma distribution. Conformity of the experimental and theoretical distributions was determined using the $\chi^{2}$ Pearson's test.

ASTM grain size numbers GS were determined by the formula [31]:

$$
G S=16.54-2.88 \cdot \ln (\bar{d})
$$

Moreover, Brinell hardness of the specimens after normalizing was measured according to EN ISO 6506-1:2014-12 with a hardness tester Zwick/Roell ZHU (Zwick Roell Gruppe, Ulm, Germany), using the ball dia. $2.5 \mathrm{~mm}$ under the load of $187.5 \mathrm{~kg}$ for $15 \mathrm{~s}$.

\section{Results and Discussion}

\subsection{Structures after Normalizing}

After normalizing, melt 1 showed ferritic-pearlitic structure (Figure 1a), typical for hypoeutectoid cast steels. Due to relatively fast air-cooling, the structure was not equilibrium and showed larger portion of laminar pearlite, or rather quasi-pearlite, than it would result from concentration of carbon in the cast steel. Hardness of the material was $177 \mathrm{HB}$ (Figure 2).

The microstructure of melt 2 was composed of ferrite and degenerate quasi-pearlite, in that cementite showed both laminar and coagulated build (Figure 1b). The pearlite portion was larger than would result from concentration of carbon in the cast steel and hardness of this melt was $153 \mathrm{HB}$, lower than that of the melt 1.

Melts 3 and 4, containing chromium that significantly increases hardenability, showed quite different structures. During air cooling being a part of normalization, the melts were subjected to partial hardening (Figure 1c,d). Their structure was composed of pearlite and acicular ferrite. A range of hardening structures could be also seen, like martensite, troostite and hardening sorbite. The hardening structures occupied a considering volume of melt 3, which resulted in its increased hardness of $421 \mathrm{HB}$, much higher than that of melt 4, equal to 298 HB (Figure 2).

Melts 5 and 6 were also subjected to partial hardening (Figure 1e,f) and their hardness values were similar, equal to 391 and $392 \mathrm{HB}$ (Figure 2). In addition to martensite and hardening troostite, their structures included degenerate pearlite and ferrite showing acicular and granular build. 


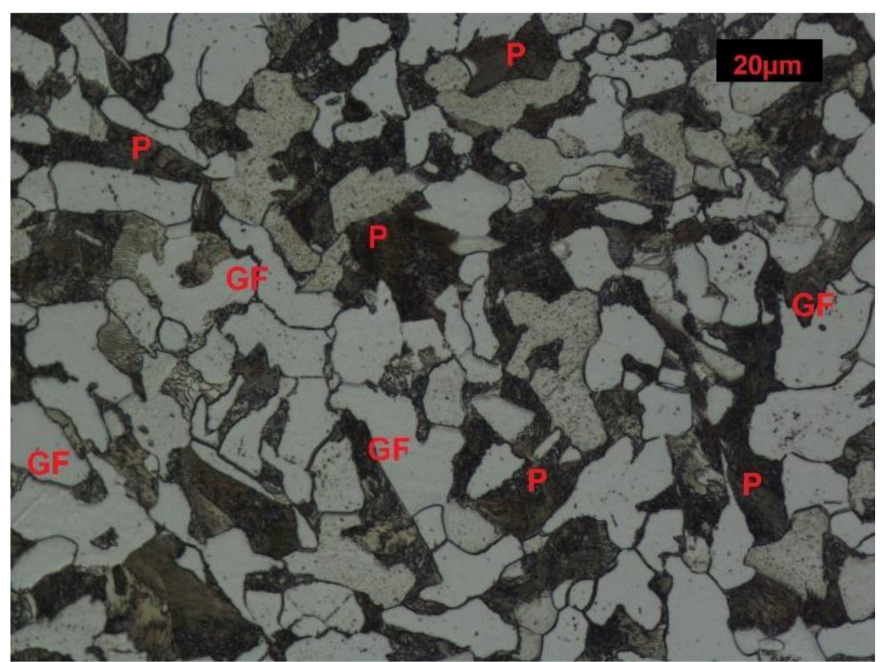

(a) Melt 1

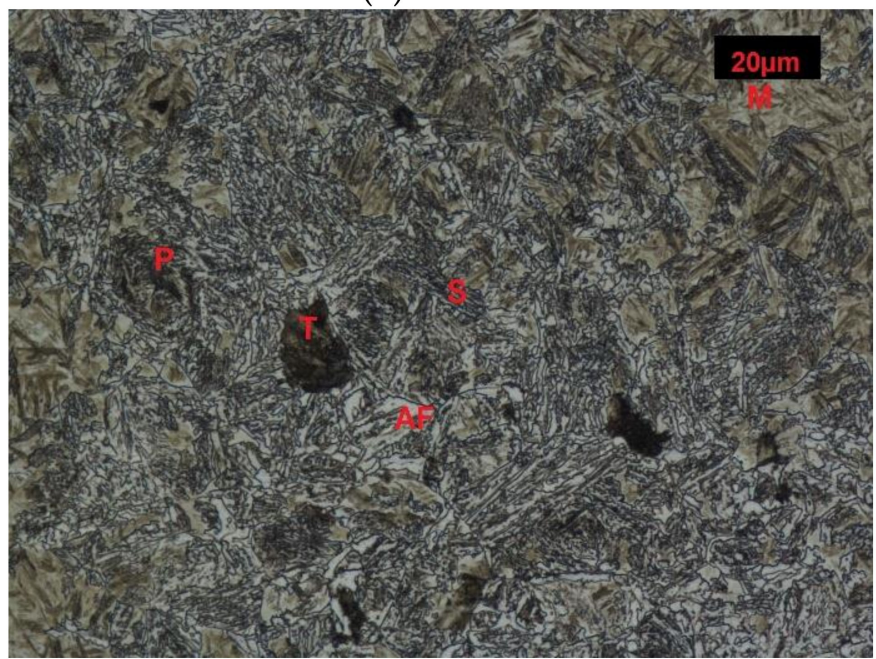

(c) Melt 3

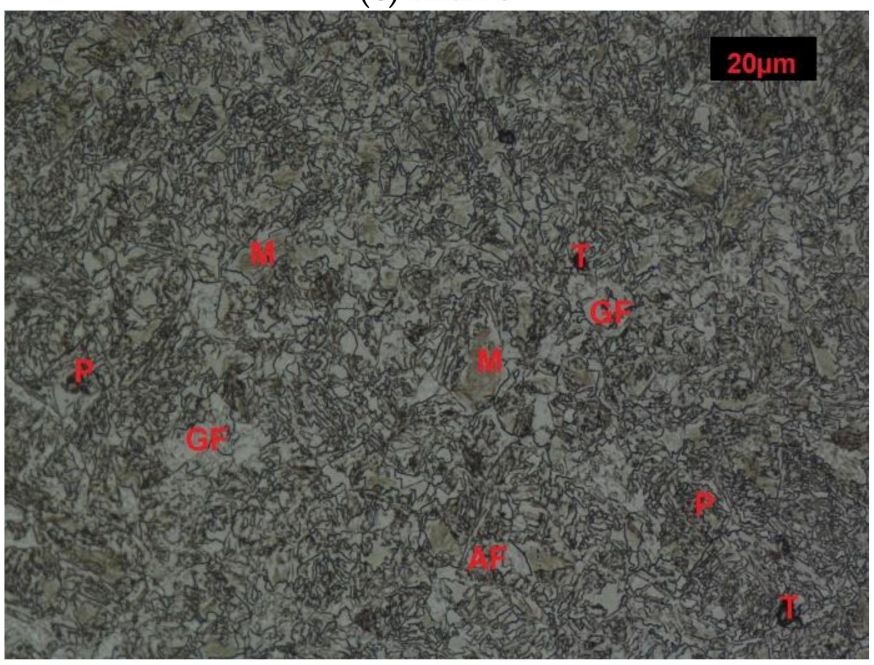

(e) Melt 5

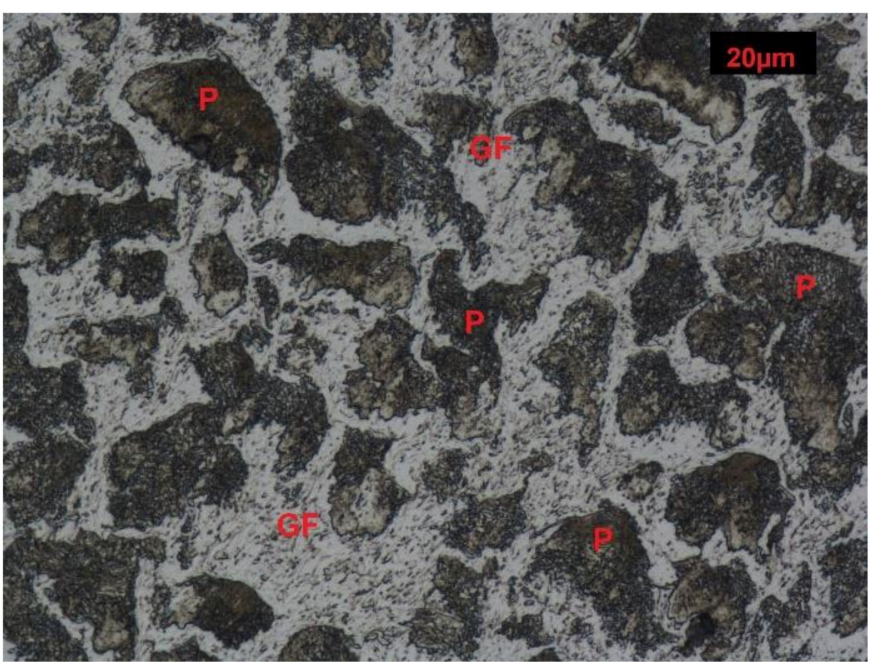

(b) Melt 2

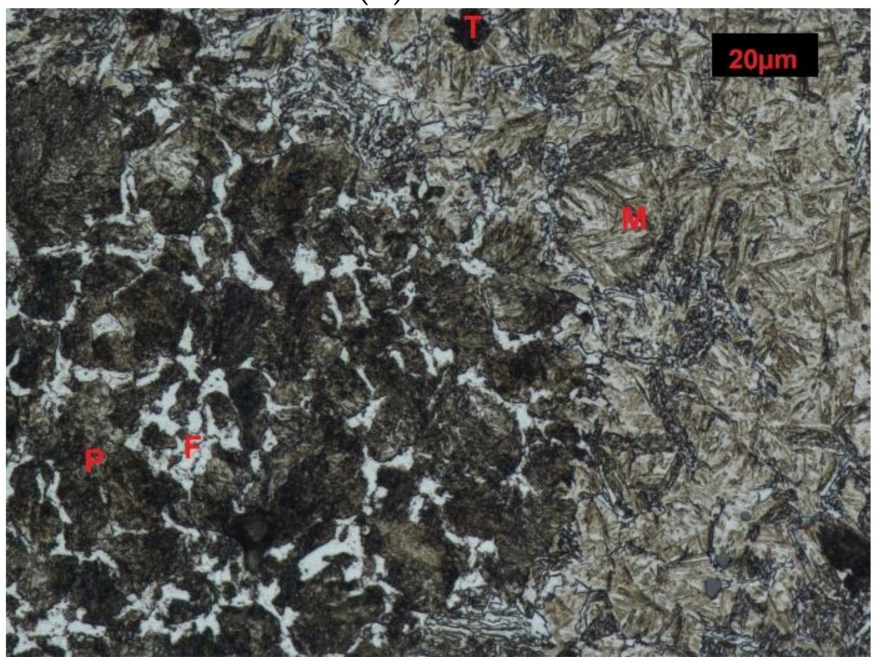

(d) Melt 4

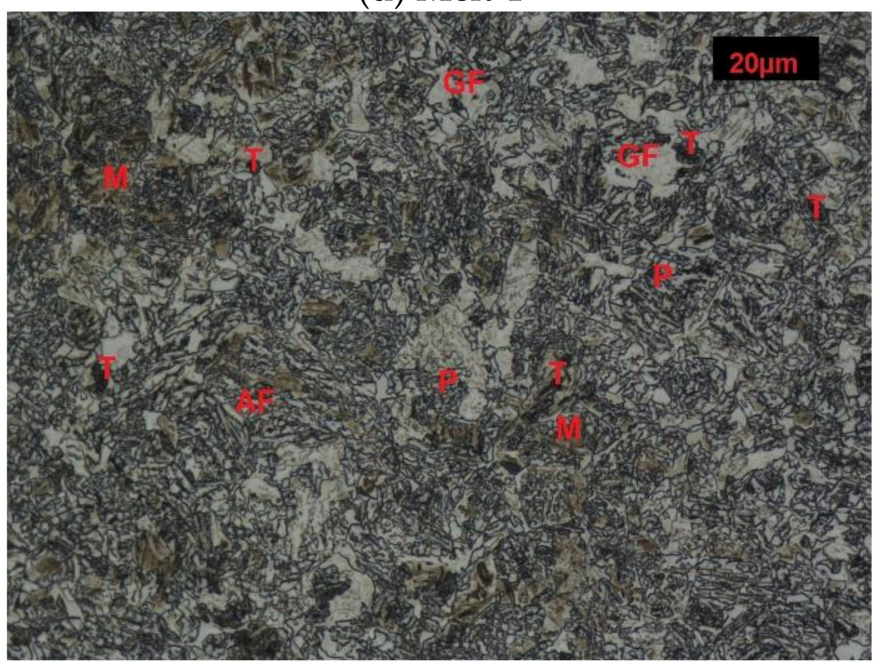

(f) Melt 6

Figure 1. Cont. 


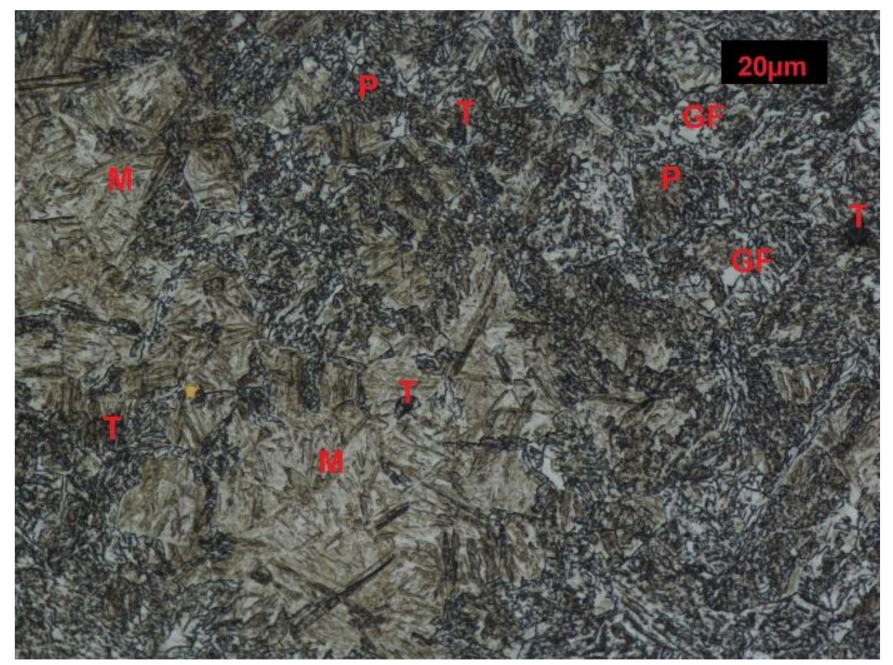

(g) Melt 7

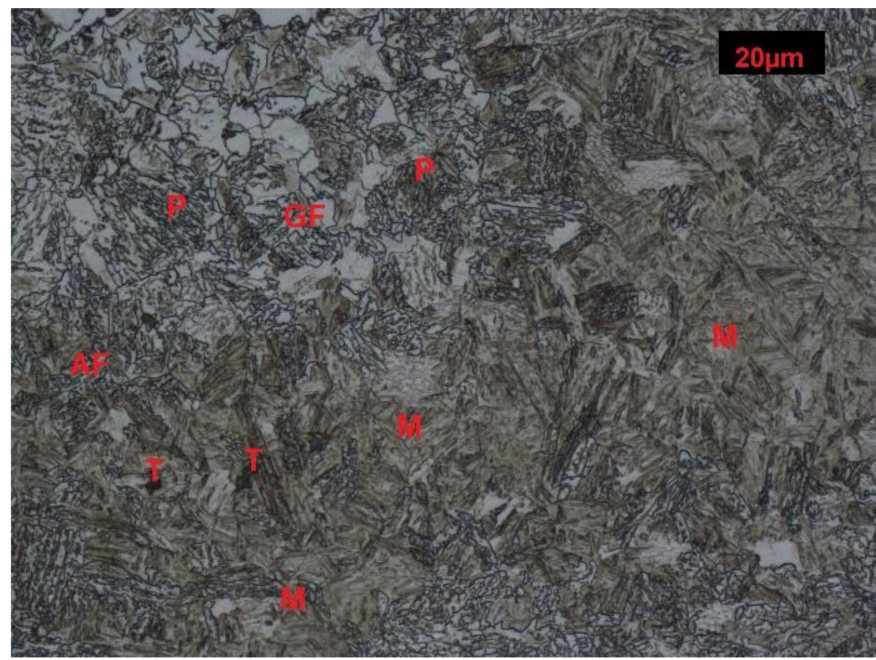

(h) Melt 8

Figure 1. Microstructures of analyzed melts after normalizing. (GF)-granular ferrite, (AF)-acicular ferrite, (P)-pearlite, (S)-sorbite, (T)-troostite, (M)-martensite. Etched, light microscopy. (a) Melt 1, (b) Melt 2, (c) Melt 3, (d) Melt 4, (e) Melt 5, (f) Melt 6, (g) Melt 7, (h) Melt 8.

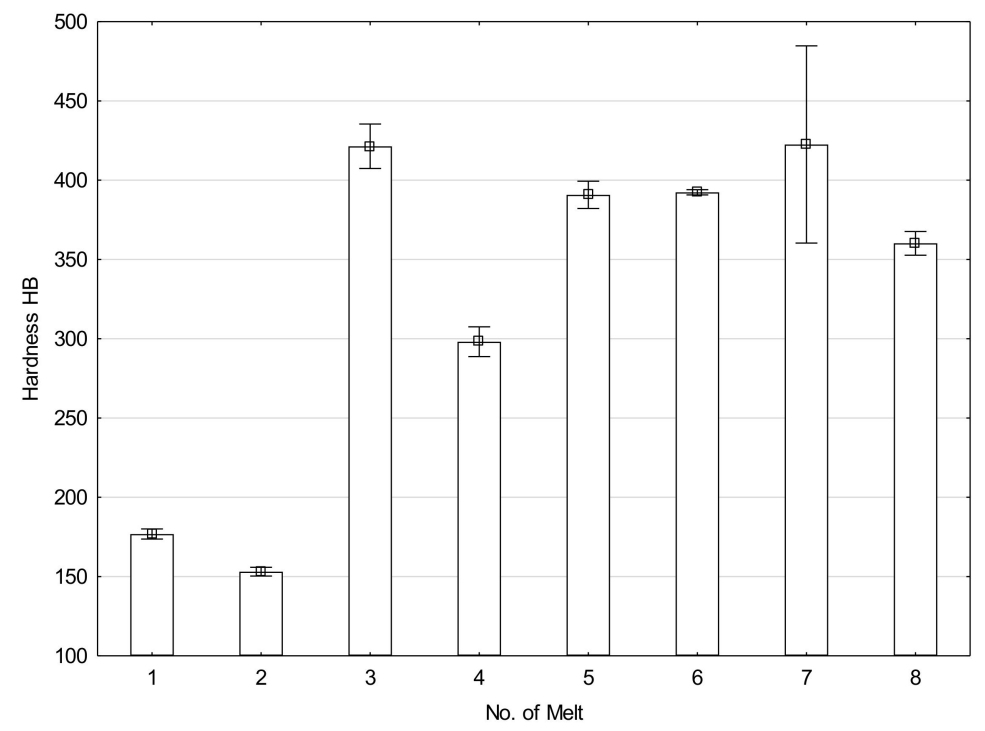

Figure 2. Hardness of analyzed melts after normalizing.

Structures of melts 7 and 8 were not typical for normalization (Figure $1 \mathrm{~g}, \mathrm{~h}$ ). The structures were composed of martensite and quench troostite, degenerate pearlite and ferrite showing acicular and granular build. Moreover, regular, yellowish precipitates of titanium nitrides were also visible. Hardness of melt 7 equal to $423 \mathrm{HB}$ was similar to that of melt 3 and hardness of melt 8 was 360 HB (Figure 2).

\subsection{Structures after Quench-Hardening}

Melt 1 was characterized by large abnormal grains (Figure 3a). After quench-hardening, in their place, a large quantity of residual austenite was visible against a background of acicular martensite. Precipitates of acicular upper bainite could be seen on grain boundaries of former austenite. Martensite in melt 2 was more fine-grained (Figure 3b). Against its background, acicular ferrite were visible. Microstructures of melts 3, 4, 5 and 6 were similar (Figure 3c-f), built of fine-lath quench-hardening martensite. Moreover, regular, yellowish precipitates of titanium nitrides could be seen in melts 3 and 5. The microstructure of melt 7 was composed of medium-lath martensite (Figure 3g). Quench-hardening martensite 
visible in the microstructure of melt 8 was more fine-grained (Figure $3 \mathrm{~h}$ ) and was similar to martensite in melt 5 .

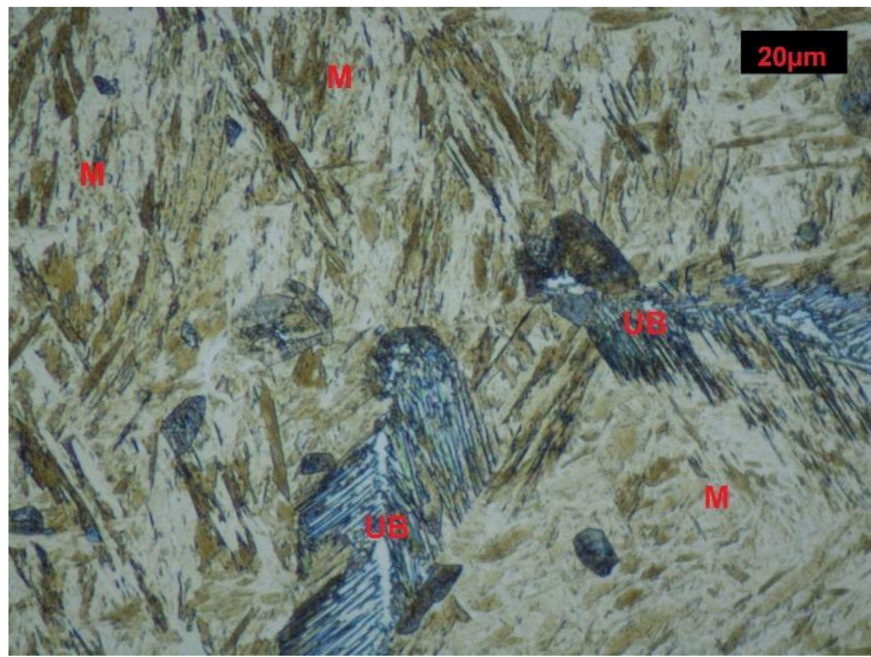

(a) Melt 1

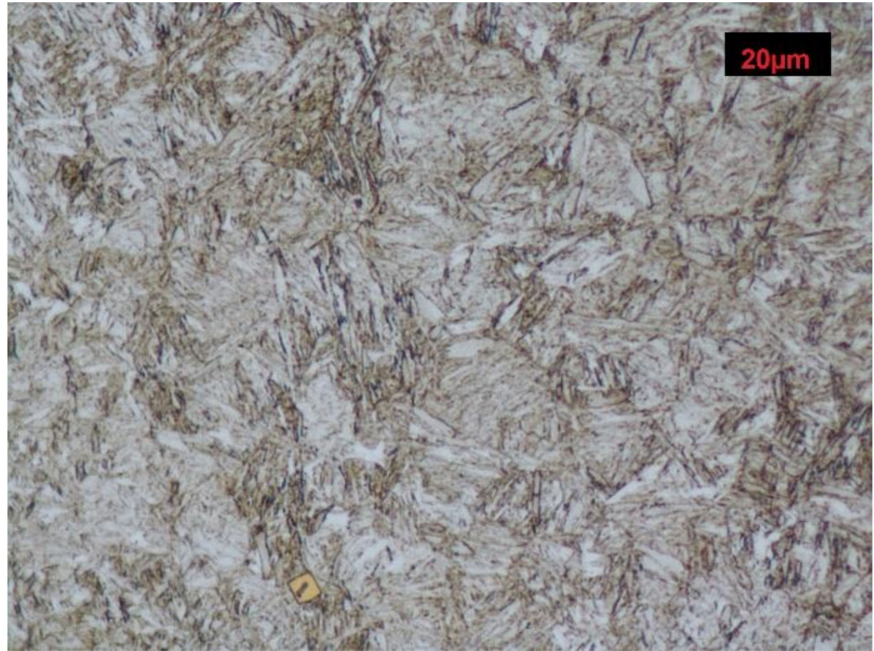

(c) Melt 3

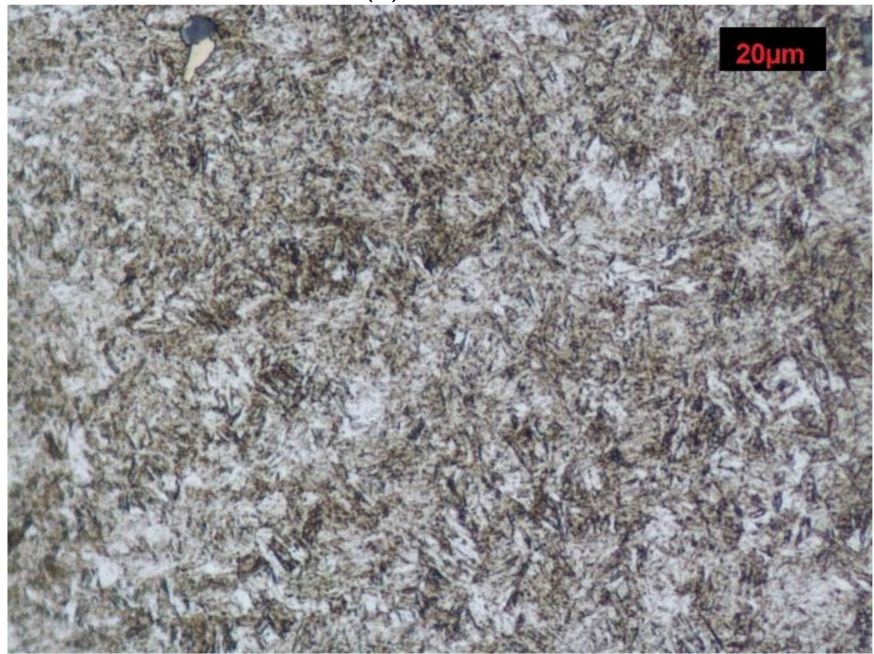

(e) Melt 5

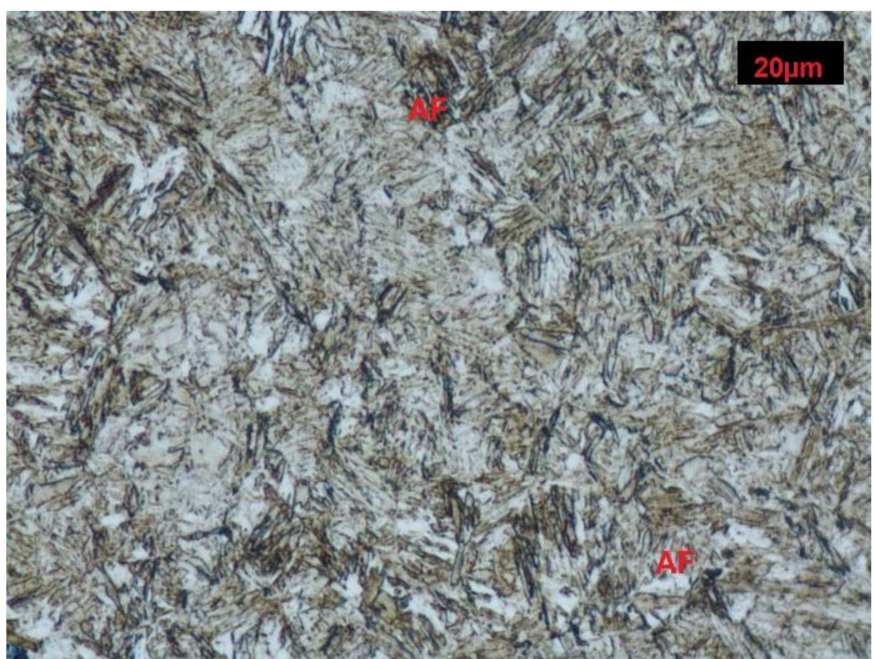

(b) Melt 2

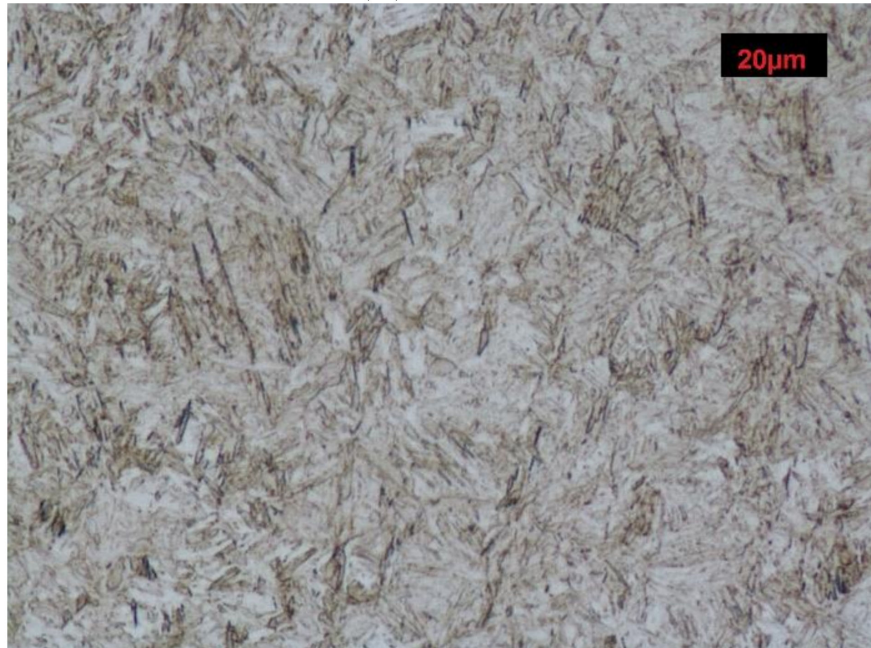

(d) Melt 4

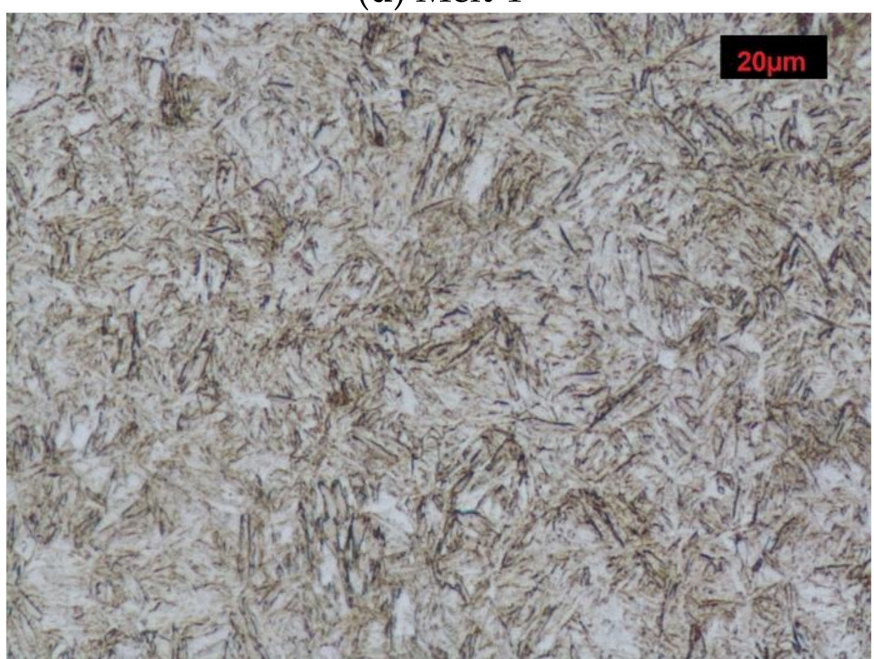

(f) Melt 6

Figure 3. Cont. 


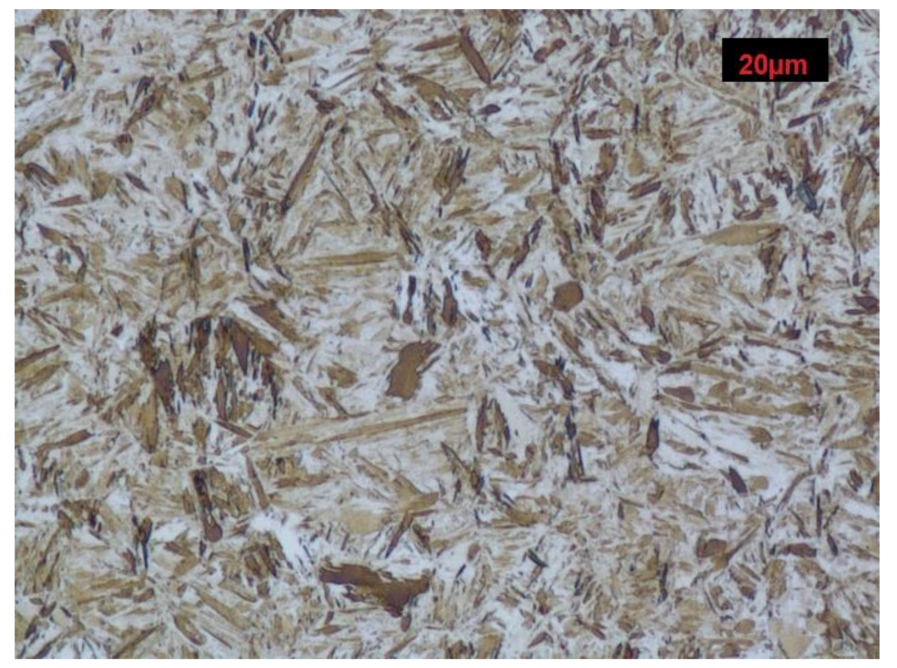

(g) Melt 7

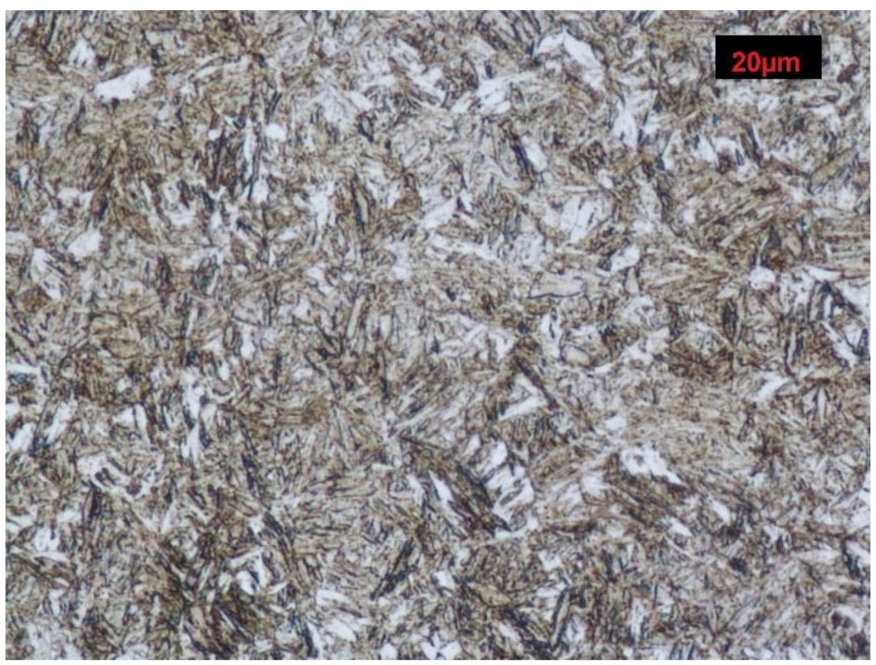

(h) Melt 8

Figure 3. Microstructures of analyzed melts after quench-hardening. (M)-martensite, (UP)-upper bainite. (AF)-acicular ferrite. Etched, light microscopy. (a) Melt 1, (b) Melt 2, (c) Melt 3, (d) Melt 4, (e) Melt 5, (f) Melt 6, (g) Melt 7, (h) Melt 8.

\subsection{Grain Size of Former Austenite}

After austenitizing at $890^{\circ} \mathrm{C}$, numerous abnormally large grains surrounded with colonies of fine grains were observed in microstructure of the melt 1 (Figure 4a). Average diameter of former austenite grains was $20.65 \mu \mathrm{m}$ and minimum and maximum values were 4.15 and $165.34 \mu \mathrm{m}$, respectively, see Table 4 . Irrespective of the abnormal grains, the smallest grains accounted for ca. $40 \%$ of all the grains (Figure $5 \mathrm{a}$ ). The obtained results could not be approximated by any theoretical distribution.

In comparison to melt 1, melt 2 did not include boron in its chemical composition, see Table 1. After austenitizing, microstructure of the melt was more homogeneous, with generally smaller grains and the occurring abnormal grains smaller and not so numerous (Figure $4 \mathrm{~b}$ ). Average austenite grain diameter and ASTM grain size GS were respectively $13.07 \mu \mathrm{m}$ and 9.14. The obtained grain size distribution after austenitizing at $870{ }^{\circ} \mathrm{C}$ could be approximated by the log-normal distribution (Figure $5 b$ ).

In the microstructure of melt 3, no abnormal grains were observed (Figure 4c). Even if the sizes of the grains were variable, the difference between the largest and the smallest measured diameter was ca. $35 \mu \mathrm{m}$ (see Table 4) and the average diameters of former austenite grains and the ASTM GS value were $11.78 \mu \mathrm{m}$ and 9.44, respectively. From the results from the obtained grain size distribution that could be approximated by the log-normal distribution, the grains smaller than $7.50 \mu \mathrm{m}$ accounted for $40 \%$ of all grains.

After austenitizing at $840{ }^{\circ} \mathrm{C}$, no significant structural qualitative differences were found in melt 4 in comparison to the boron-containing melt 3 , see Figure $4 \mathrm{~d}$ and Table 4 . No abnormal grains were found, although the structure was composed of different-size grains, whose diameters ranged from $1.77 \mu \mathrm{m}$ to over $25 \mu \mathrm{m}$. Grain size GS was 10.42 . The obtained grain size distribution could not be approximated by the log-normal distribution.

In comparison to melt 3 which, was austenitized at a temperature only $10^{\circ} \mathrm{C}$ higher, melt 5 showed smaller and more uniform grains (Figure 4e). Minimum diameter of former austenite grains was $2.29 \mu \mathrm{m}$, maximum diameter reached $18.43 \mu \mathrm{m}$ and the ASTM GS value was 10.95 (Table 4).

Average grain diameter and the ASTM GS value of melt 6 after austenitizing at $870{ }^{\circ} \mathrm{C}$ were $5.89 \mu \mathrm{m}$ and 11.43 , respectively, see Table 4 . The grains were fine and uniform (Figure $4 \mathrm{f}$ ), with the difference between minimum and maximum grain diameters amounted to about $15 \mu \mathrm{m}$. 


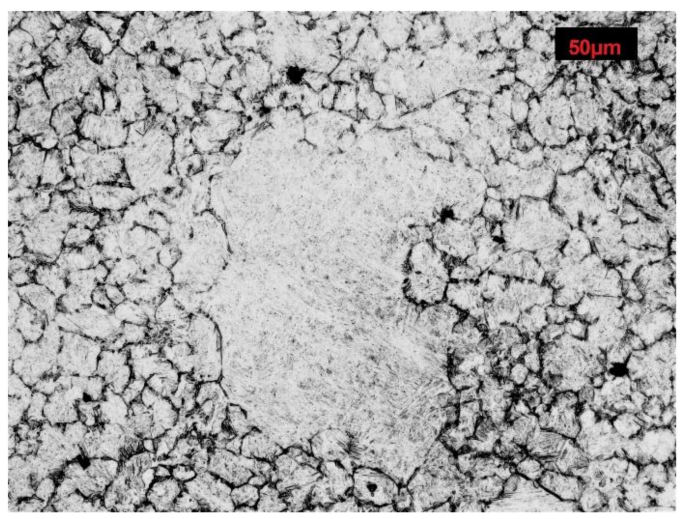

(a) Melt 1

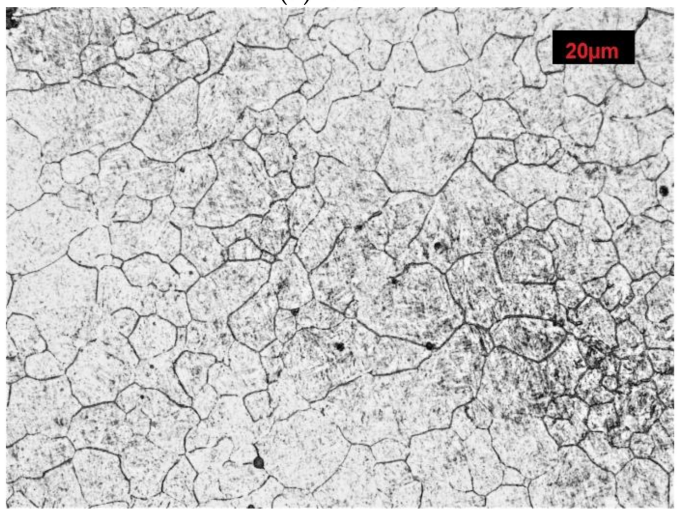

(c) Melt 3

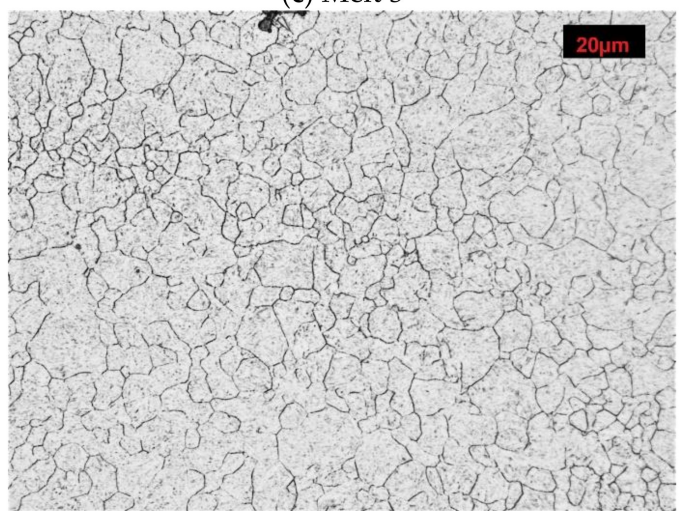

(e) Melt 5

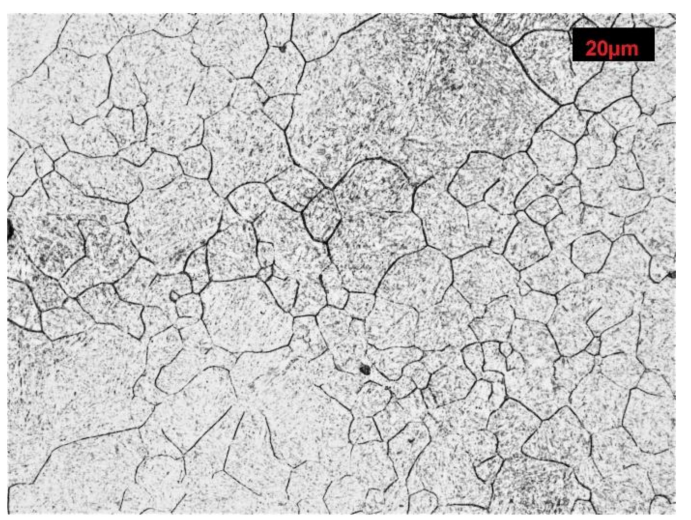

(g) Melt 7

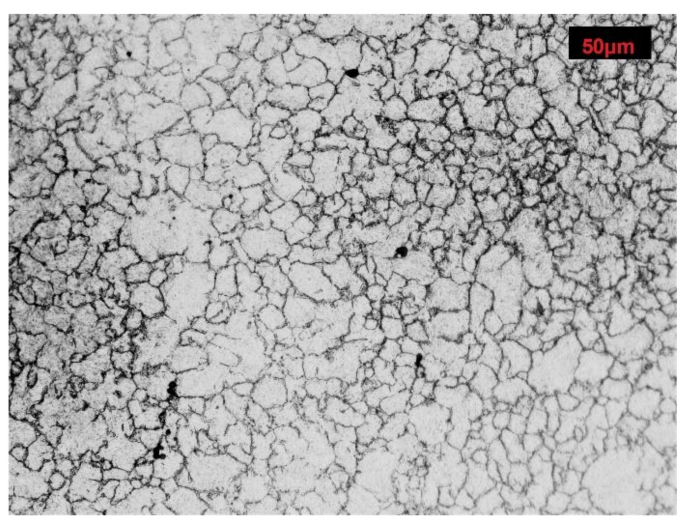

(b) Melt 2

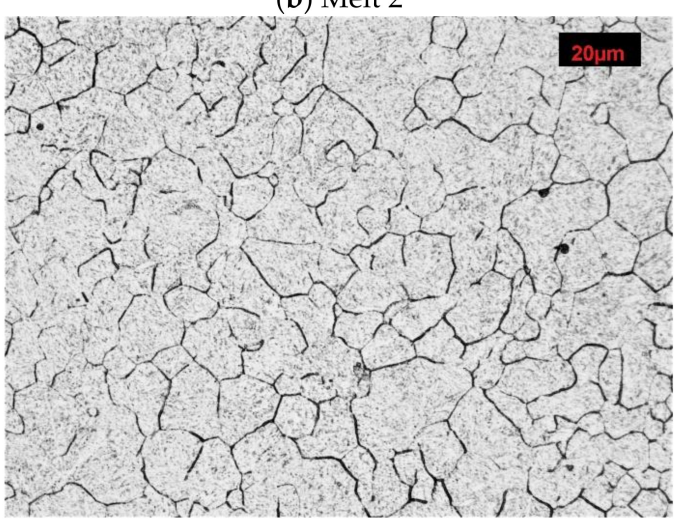

(d) Melt 4

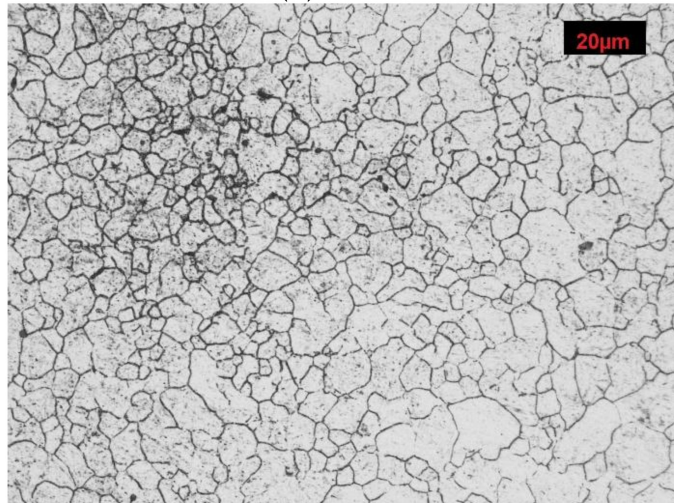

(f) Melt 6

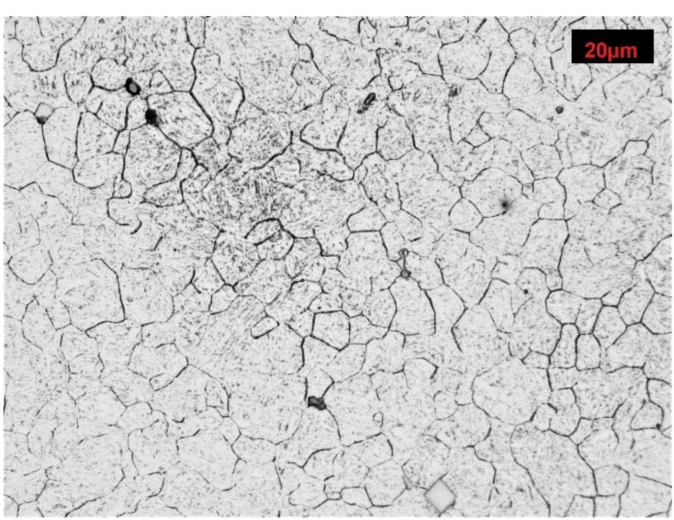

(h) Melt 8

Figure 4. Microstructures of analyzed melts with revealed former austenite grain. Etched, light microscopy. (a) Melt 1, (b) Melt 2, (c) Melt 3, (d) Melt 4, (e) Melt 5, (f) Melt 6, (g) Melt 7, (h) Melt 8. 
Table 4. Descriptive statistics of grain diameter distributions and ASTM grain size GS obtained for the analyzed melts.

\begin{tabular}{|c|c|c|c|c|c|}
\hline $\mathrm{T}_{\mathrm{A}}\left({ }^{\circ} \mathrm{C}\right)$ & Average Diameter $(\mu \mathrm{m})$ & Median $(\mu \mathrm{m})$ & Minimum ( $\mu \mathrm{m})$ & Maximum $(\mu \mathrm{m})$ & ASTM Grain Size \\
\hline \multirow[t]{2}{*}{890} & & & Melt 1 & & \\
\hline & 20.65 & 17.69 & 4.15 & 165.34 & 7.82 \\
\hline \multirow[t]{2}{*}{870} & & & Melt 2 & & \\
\hline & 13.07 & 10.53 & 3.42 & 43.08 & 9.14 \\
\hline \multirow[t]{2}{*}{830} & & & Melt 3 & & \\
\hline & 11.78 & 9.11 & 3.08 & 38.29 & 9.44 \\
\hline \multirow[t]{2}{*}{840} & & & Melt 4 & & \\
\hline & 8.36 & 6.32 & 1.77 & 25.04 & 10.42 \\
\hline \multirow[t]{2}{*}{840} & & & Melt 5 & & \\
\hline & 6.97 & 6.20 & 2.29 & 18.43 & 10.95 \\
\hline \multirow[t]{2}{*}{870} & & & Melt 6 & & \\
\hline & 5.89 & 4.97 & 1.45 & 16.78 & 11.43 \\
\hline \multirow[t]{2}{*}{810} & & & Melt 7 & & \\
\hline & 10.88 & 9.67 & 2.01 & 50.71 & 9.67 \\
\hline \multirow[t]{2}{*}{890} & & & Melt 8 & & \\
\hline & 8.50 & 8.07 & 1.77 & 20.59 & 10.38 \\
\hline
\end{tabular}

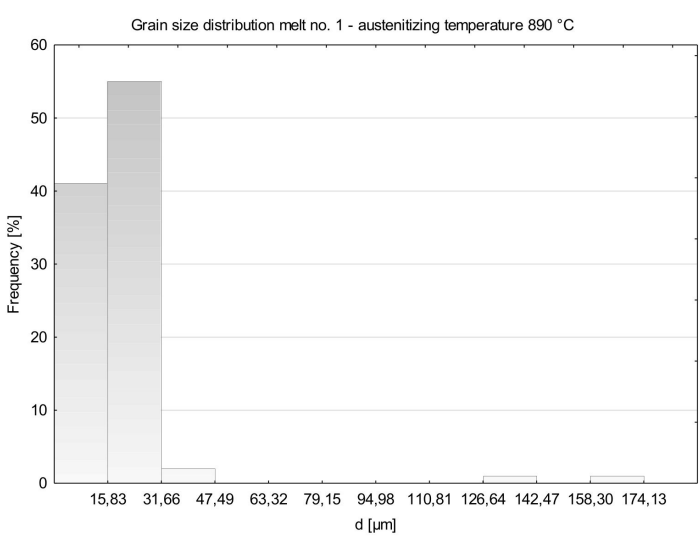

(a) Melt 1

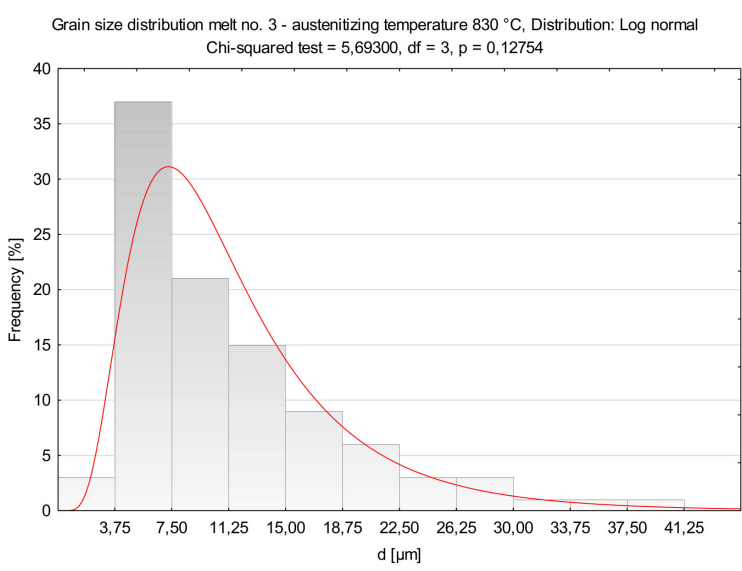

(c) Melt 3

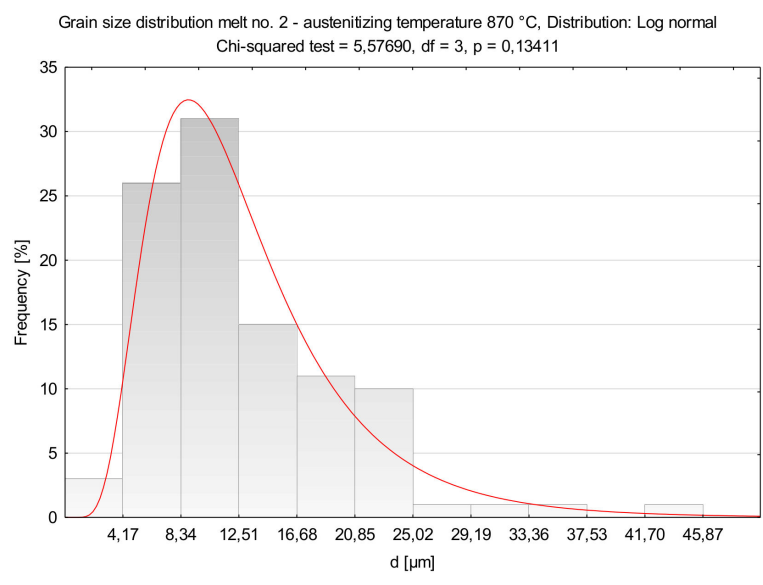

(b) Melt 2

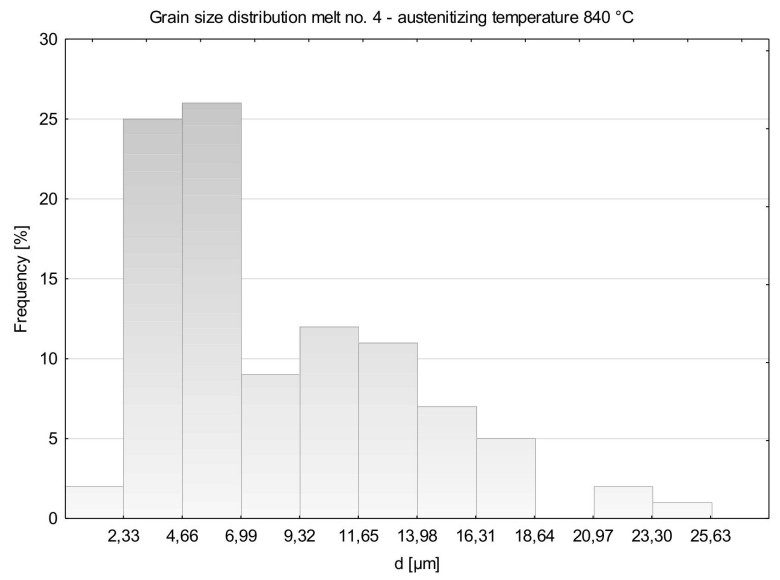

(d) Melt 4

Figure 5. Cont. 


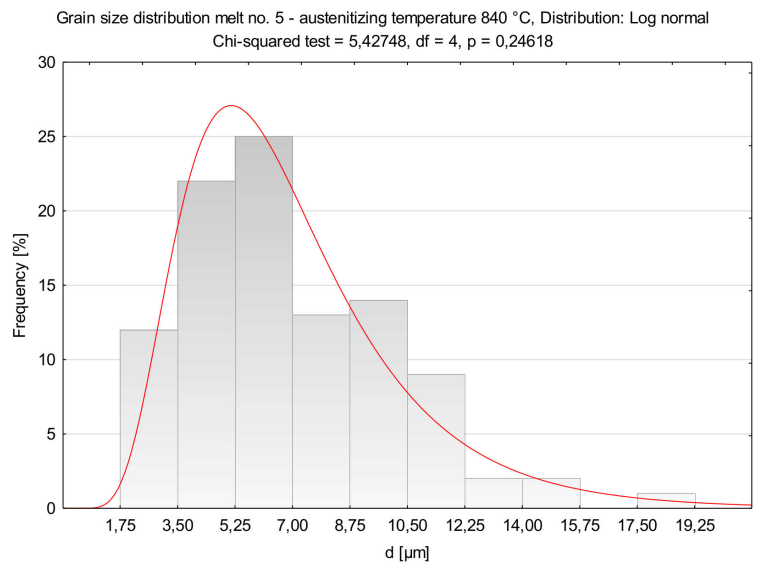

(e) Melt 5

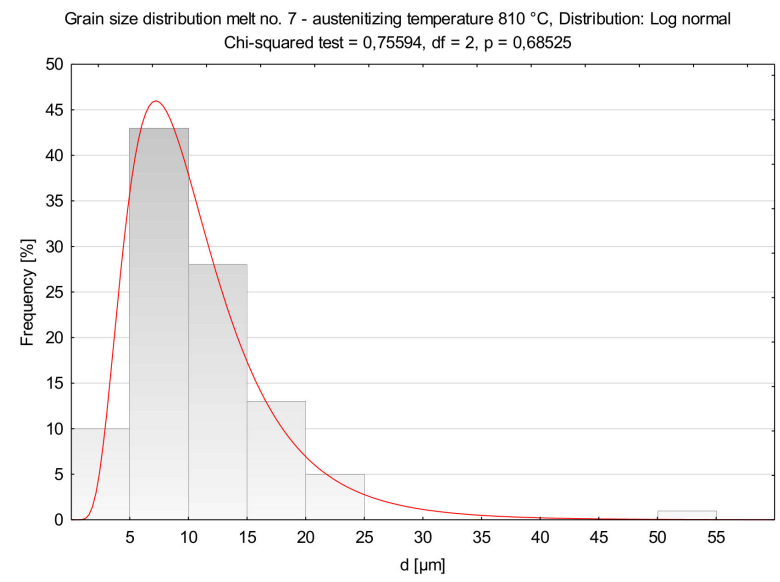

(g) Melt 7

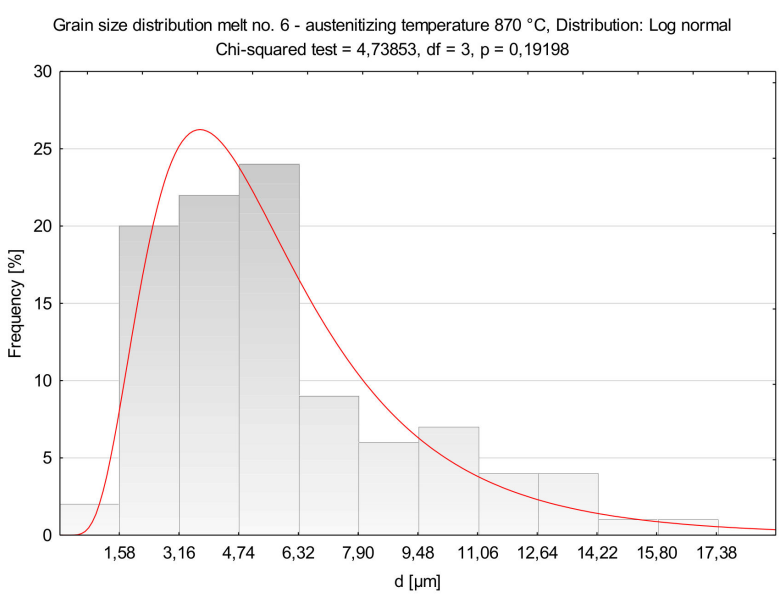

(f) Melt 6

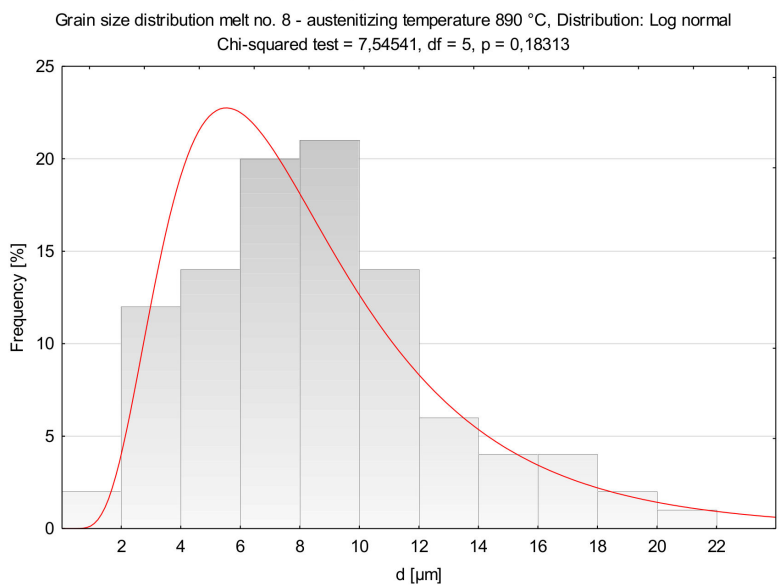

(h) Melt 8

Figure 5. Distributions of austenite grain diameters of the analyzed melts. (a) Melt 1, (b) Melt 2, (c) Melt 3, (d) Melt 4, (e) Melt 5, (f) Melt 6, (g) Melt 7, (h) Melt 8.

After austenitizing at $810^{\circ} \mathrm{C}$, melt 7 was characterized by quite large, irregular grains (Figure $4 \mathrm{~g}$ ), even though, apart from boron, it contained $0.019 \%$ of titanium, see Table 4 . The structure included abnormal grains surrounded with colonies of smaller grains. Very fine grains with diameters below $5 \mu \mathrm{m}$ accounted for ca. $5 \%$ only (Figure $5 \mathrm{~g}$ ). ASTM grain size GS was equal to 9.67.

In melt 8 , grains were generally fine and more uniform and its structure was similar to that obtained in melt 4 , austenitized at a temperature $50^{\circ} \mathrm{C}$ lower. No abnormal grains were found (Figure 4h). ASTM grain size GS was 10.38, average grain diameter $8.50 \mu \mathrm{m}$, median was close to the average value and minimum and maximum diameters were $1.77 \mu \mathrm{m}$ and $20.59 \mu \mathrm{m}$, respectively (Table 4).

The obtained distributions of the melts 3, 5, 6, 7 and 8 could be approximated by the log-normal distribution.

\subsection{Jominy of Hardenability Test}

Figures 6 and 7 show hardenability curves of the analyzed melts. In the collective chart (Figure 6), clear differences of hardenability are visible between the melts 1 and 2 and the other melts. The first pair of melts was characterized by low hardenability (Figure 7a) and the measured hardness values dropped very rapidly with the distance from the specimen end face. Basically, there were no differences of hardenability between the melt containing boron and the melt free of boron, and the distances of semi-martensitic zones from the specimen end faces were 1.7 and $2.0 \mathrm{~mm}$, respectively. Additives of chromium in melts 3 and 4 improved their hardenability and their hardenability curves did not show a big 
drop of hardness measured deeper into the specimens (Figure $7 \mathrm{~b}$ ). Like in the previously analyzed melts, no significant differences of hardenability were noticed between them. The distances of semi-martensitic zones from the specimen end faces were 27.5 and $25.0 \mathrm{~mm}$. Differences in hardenability curves could be seen between melts 5 and 6 only (Figure 7c). The obtained curves could basically be considered parallel, but the curve for melt 6 was shifted towards lower hardness values. The distance of the semi-martensitic zone from the specimen end face was $35.0 \mathrm{~mm}$ for melt 5 and $23.5 \mathrm{~mm}$ for melt 6 . Between the melts 7 and 8 , there was the biggest difference in carbon concentration among all the analyzed melts. At the beginning, the hardness values were similar, but started differing significantly at a distance of $10 \mathrm{~mm}$ from the specimen end face (Figure $7 \mathrm{~d}$ ) and the curve for the melt 7 was moved towards lower hardness values. The read-out distances of semi-martensitic zones from the specimen face ends for melts 7 and 8 were 20.0 and $45.0 \mathrm{~mm}$, respectively.

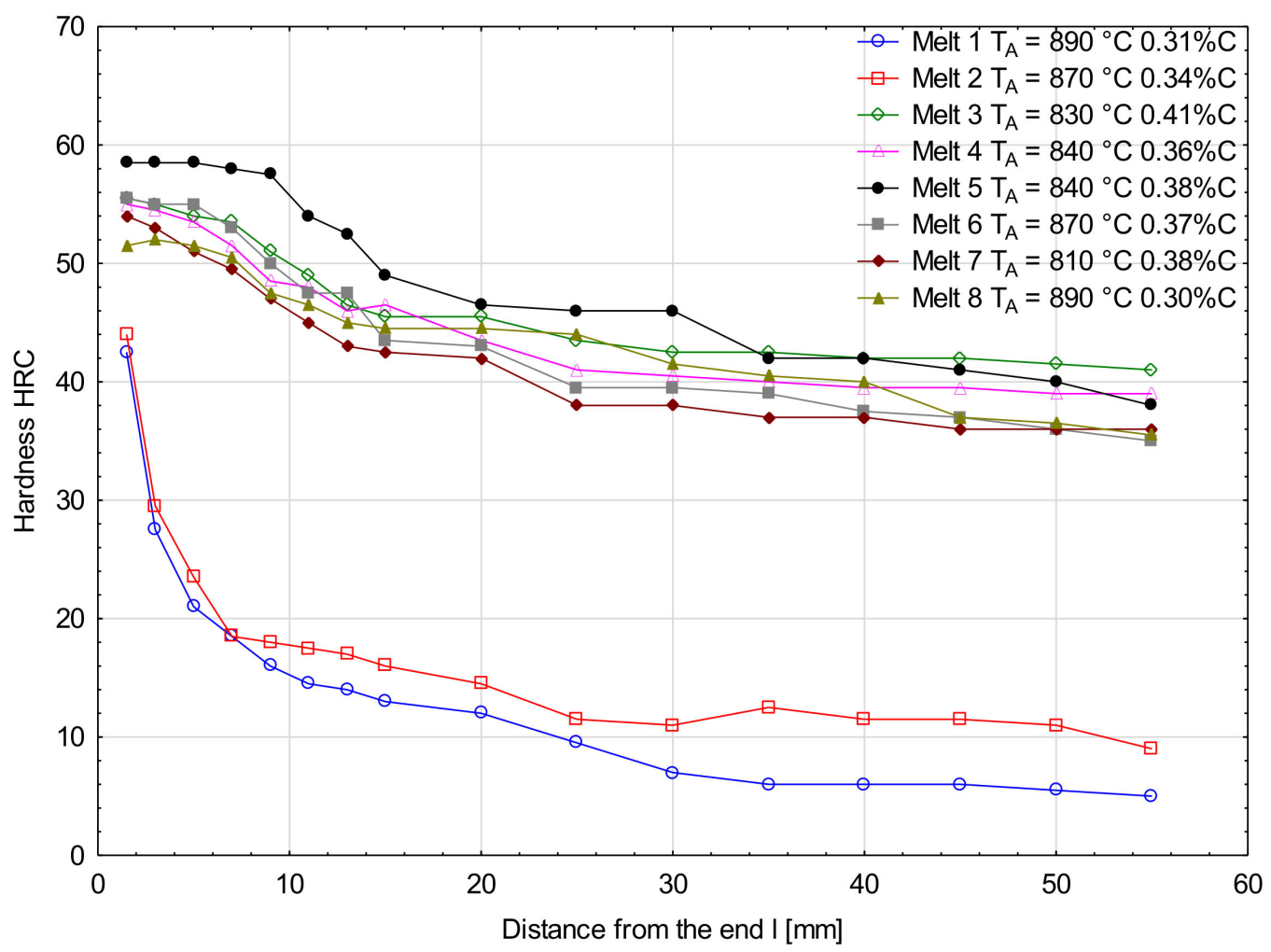

Figure 6. Hardenability curves for the analyzed melts.

The examined melts were characterized by significant differences of hardenability, see Tables 9-12. The values of ideal critical diameters $D_{I J}$ determined on the grounds of hardenability curves ranged between 13.5-154.1 mm, while the lowest diameters were found for the melts 1 and 2 (Table 9) and the highest diameters-for the melts 5 and 8, see Tables 11 and 12. The ideal critical diameters $D_{\text {IJc }}$ of melts $1,3,5$ and 7, corrected by the temperature factor, ranged within $12.8-141.9 \mathrm{~mm}$, while the lowest value was found for melt 1 and the highest value for melt 5 . After introducing an additional correction, apart from those related to chemical composition and grain size, the following range of ideal critical diameters were obtained for the boron-containing melts: 16.3-141.6 mm. As regards to the critical diameters $D_{I}$ calculated by the Grossmann's method, only the diameter readout from the hardenability curve for melt 8 was consistent with the empirical value, see Table 12 . The values of boron hardenability factors ranged between $0.73-1.26$. For melts 1 and 2, this factor was equal to 1.04 (Table 9), so it can be seen that, in the case of the steel free of microadditives, influence of boron on improvement of hardenability is negligible. This can result more from austenite grain growth and to a lesser extent from the action of boron that is mostly bound in nitrides and its smaller quantity only is dissolved. It was similar 
when chromium was added to the melt, see Table 10. An addition of chromium significantly improves hardenability, but the mechanism of its action is different than that of boron. The boron hardenability factor for melt 3 was 0.91 . Therefore, with no other microadditives in steel, the benefits resulting from boron as the intensifier of hardenability are lost. It is only an addition of $0.26 \%$ of vanadium, accompanied by $0.99 \%$ of chromium, that significantly improved effectiveness of $0.003 \%$ of boron to the $f_{2}$ value of 1.26 (Table 11 ), even if titanium content was below its alloying concentration. The effect of vanadium can result from the fact that it bonds a part of nitrogen, thus increasing the amount of boron dissolved in austenite. However, it should be taken into consideration that vanadium shows weaker affinity for nitrogen than boron. Therefore, when vanadium is introduced individually, its concentration must be higher than $0.2 \%$ to increase effectiveness of boron, since its sufficient quantity only is able to bond nitrogen. Concentrations of vanadium in melts 5 and 6 were similar, with the value even higher in melt 6 , so the observed hardenability increase of the melt 5 was strictly related to the boron content. Thus, it can be said that an addition of $0.26 \%$ of vanadium effectively protected boron against nitrogen, ensuring the amount of boron in austenite is sufficient to inhibit its decomposition effectively.

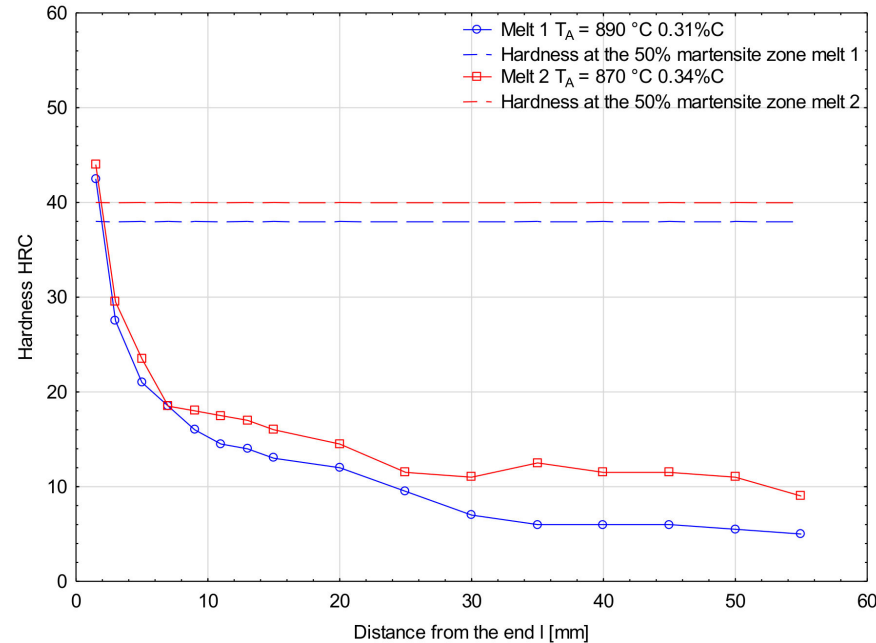

(a) Melts 1 and 2

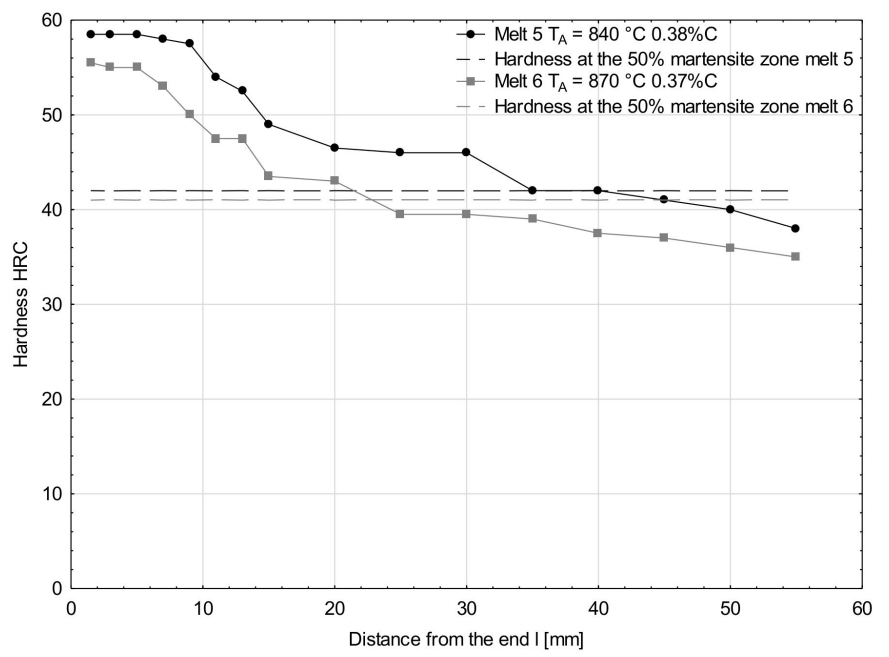

(c) Melts 5 and 6

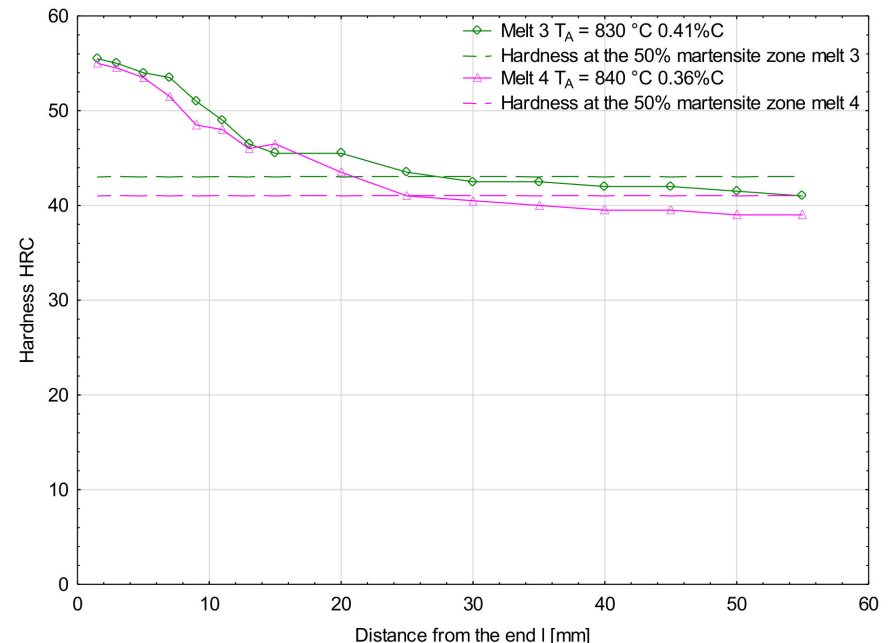

(b) Melts 3 and 4

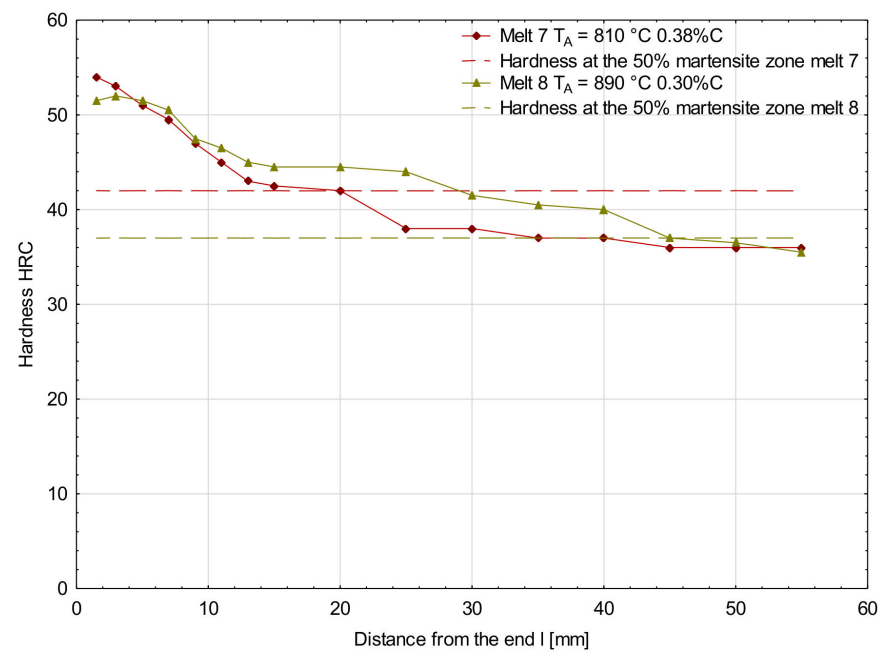

(d) Melts 7 and 8

Figure 7. Hardenability curves for the analyzed melts together with hardness values of semi-martensitic zones. (a) Melts 1 and 2, (b) Melts 3 and 4, (c) Melts 5 and 6, (d) Melts 7 and 8.

The way of calculation of boron hardenability factors is shown in Tables 5-8. 
Table 5. Calculation procedure of boron hardenability factors for the melts 1 and 2.

\begin{tabular}{|c|}
\hline $\begin{array}{l}\text { ASTM Grain size GS of the melt } 1 \text { : } \\
\text { GS }=16.54-2.88 \times \ln (20.65) \\
\text { GS }=7.82 \\
\text { ASTM Grain size GS of the melt } 2: \\
\text { GS }=16.54-2.88 \times \ln (13.07) \\
\text { GS }=9.14\end{array}$ \\
\hline $\begin{array}{l}\text { Ideal critical diameter } D_{I J} \text { of the melt } 1 \text { : } \\
\qquad D_{I J}=13.5 \mathrm{~mm} \\
\text { Ideal critical diameter } D_{I J} \text { of the melt } 2 \text { : } \\
\qquad D_{I J}=15.7 \mathrm{~mm}\end{array}$ \\
\hline $\begin{array}{c}\text { Correction factor } f_{\text {corr }} \text { for the melt } 1: \\
f_{\text {corr }}=6.4217+3.78 \times 10^{-3} \times 890-0.2964 \times 890^{2} \\
f_{\text {corr }}=-234769 \\
\text { Correction factor } f_{\text {corr }} \text { for the melt } 2: \\
f_{\text {corr }}=6.4217+3.78 \times 10^{-3} \cdot 870-0.2964 \times 870^{2} \\
f_{\text {corr }}=-224335\end{array}$ \\
\hline $\begin{array}{l}\text { Corrected distance of semi-martensitic zone } J_{c} \text { for the melt } 1 \text { : } \\
\qquad \begin{array}{l}J_{c}=1.7 \times-234769 \\
J_{c}=1.6 \mathrm{~mm}\end{array}\end{array}$ \\
\hline $\begin{array}{l}\text { Corrected critical diameter } D_{I J c} \text { of the melt } 1: \\
\qquad D_{I J c}=12.8 \mathrm{~mm}\end{array}$ \\
\hline $\begin{array}{c}\text { Corrected critical diameter } D_{\text {IJccorr }} \text { of the melt } 1: \\
D_{\text {IJcorr }}=12.8 \times \frac{12.828094 \times 1.596583 \times 1.132576 \times 1.015542 \times 1.022943 \times 1.023385}{12.861536 \times 1.268579 \times 1.121201 \times 1.017954 \times 1.020625 \times 1.017096} \\
D_{\text {IJcorr }}=16.3 \mathrm{~mm}\end{array}$ \\
\hline $\begin{array}{l}\text { Factor } f_{2}: \\
f_{2}=\frac{16.3}{15.7} \\
f_{2}=1.04\end{array}$ \\
\hline
\end{tabular}

Table 6. Calculation procedure of boron hardenability factors for the melts 3 and 4 .

\begin{tabular}{|c|}
\hline $\begin{array}{l}\text { ASTM Grain size GS of the melt } 3 \text { : } \\
\qquad \begin{array}{l}\text { GS }=16.54-2.88 \times \ln (11.78) \\
\text { GS }=9.44\end{array} \\
\text { ASTM Grain size GS of the melt } 4 \text { : } \\
\quad G S=16.54-2.88 \times \ln (8.36) \\
\text { GS }=10.42\end{array}$ \\
\hline $\begin{array}{l}\text { Ideal critical diameter } D_{I J} \text { of the melt 3: } \\
\qquad D_{I J}=122.4 \mathrm{~mm} \\
\text { Ideal critical diameter } D_{I J} \text { of the melt } 4 \text { : } \\
\qquad D_{I J}=114.9 \mathrm{~mm}\end{array}$ \\
\hline $\begin{aligned} & \text { Correction factor } f_{\text {corr }} \text { for the melt } 3: \\
& f_{\text {corr }}= 6.4217+3.78 \times 10^{-3} \times 830-0.2964 \times 830^{2} \\
& f_{\text {corr }}=-204180 \\
& \text { Correction factor } f_{\text {corr }} \text { for the melt } 4: \\
& f_{\text {corr }}=6.4217+3.78 \times 10^{-3} \times 840-0.2964 \times 840^{2} \\
& f_{\text {corr }}=-209130\end{aligned}$ \\
\hline $\begin{array}{l}\text { Corrected distance of semi-martensitic zone } J_{c} \text { for the melt 3: } \\
\qquad \begin{array}{c}J_{c}=27.5 \times \frac{-204180}{-209130} \\
J_{c}=28.2 \mathrm{~mm}\end{array}\end{array}$ \\
\hline $\begin{array}{l}\text { Corrected critical diameter } D_{I J c} \text { of the melt 3: } \\
\qquad D_{I J c}=122.9 \mathrm{~mm}\end{array}$ \\
\hline $\begin{array}{c}\text { Corrected critical diameter } D_{\text {IJccorr }} \text { of the melt } 3: \\
D_{\text {IJcorr }}=122.9 \times \frac{12.600000 \times 2.893914 \times 1.136393 \times 1.02401 \times 1.901615 \times 1.027335}{14.086873 \times 2.848379 \times 1.155673 \times 1.02401 \times 1.974884 \times 1.035681} \\
D_{\text {IJcorr }}=104.4 \mathrm{~mm}\end{array}$ \\
\hline $\begin{array}{l}\text { Factor } f_{2}: \\
f_{2}=\frac{104.4}{114.9} \\
f_{2}=0.91\end{array}$ \\
\hline
\end{tabular}


Table 7. Calculation procedure of boron hardenability factors for the melts 5 and 6.

\begin{tabular}{|c|}
\hline $\begin{array}{l}\text { ASTM Grain size GS of the melt } 5: \\
\text { GS }=16.54-2.88 \times \ln (6.97) \\
\text { GS }=10.95 \\
\text { ASTM Grain size GS of the melt } 6: \\
\text { GS }=16.54-2.88 \times \ln (5.89) \\
\text { GS }=11.43\end{array}$ \\
\hline $\begin{array}{l}\text { Ideal critical diameter } D_{I J} \text { of the melt } 5 \text { : } \\
\qquad D_{I J}=137.1 \mathrm{~mm} \\
\text { Ideal critical diameter } D_{I J} \text { of the melt } 6 \text { : } \\
\qquad D_{i I}=112.1 \mathrm{~mm}\end{array}$ \\
\hline $\begin{array}{c}\text { Correction factor } f_{\text {corr }} \text { for the melt } 5: \\
f_{\text {corr }}=6.4217+3.78 \times 10^{-3} \times 840-0.2964 \times 840^{2} \\
f_{\text {kor }}=-209130 \\
\text { Correction factor } f_{\text {corr }} \text { for the melt } 6: \\
f_{\text {corr }}=6.4217+3.78 \times 10^{-3} \times 870-0.2964 \times 870^{2} \\
f_{\text {corr }}=-224335\end{array}$ \\
\hline $\begin{array}{l}\text { Corrected distance of semi-martensitic zone } J_{c} \text { for the melt 5: } \\
\qquad \begin{array}{c}J_{c}=35.0 \times \frac{-224335}{-209130} \\
J_{c}=37.5 \mathrm{~mm}\end{array}\end{array}$ \\
\hline $\begin{array}{l}\text { Corrected critical diameter } D_{I J \mathcal{c}} \text { of the melt 5: } \\
\qquad D_{I J \mathcal{c}}=141.9 \mathrm{~mm}\end{array}$ \\
\hline $\begin{array}{c}\text { Corrected critical diameter } D_{\text {IJccorr }} \text { of the melt } 5: \\
D_{I J \text { corr }}=141.9 \times \frac{12.773801 \times 3.034934 \times 1.163477 \times 1.02401 \times 2.082228 \times 1.029316}{12.945269 \times 2.963585 \times 1.171322 \times 1.020372 \times 2.113955 \times 1.023385} \\
D_{\text {IJcorr }}=141.6 \mathrm{~mm}\end{array}$ \\
\hline $\begin{array}{l}\text { Factor } f_{2}: \\
f_{2}=\frac{141.6}{112.1} \\
f_{2}=1.26\end{array}$ \\
\hline
\end{tabular}

However, the situation is interesting in melts 7 and 8, see Table 12. Melt 7 contained less titanium than its alloying concentration, because such quantities of titanium are commonly added to one of the most popular micro-alloy steels. Hardenability of melt 7 was lower than that of melt 8 and its factor $f_{2}$ was equal to 0.73 . This is an interesting observation, since content of titanium, as the element with high affinity for nitrogen, clearly influences quantity of boron dissolved in austenite and, in this case, only boron would improve hardenability. Nakasato and Takahashi [34] showed that the addition of titanium at the level of $\mathrm{min} .0 .02 \%$ allows free nitrogen to be bound by forming TiN and enables boron to remain in solution. In the absence of titanium, it is important to maintain the low nitrogen content of only 30-40 ppm and a sufficiently high amount of aluminum (350-500 ppm). In melt 7, the titanium content at the level of $0.019 \%$ was found to be insufficient for effective present nitrogen binding, probably mainly due to a higher nitrogen content than recommended by Nakasato and Takahashi. Therefore, insufficient quantity of nitride-forming elements will result in losing the favorable effect of boron as the hardenability improving element or will even reduce hardenability. 
Table 8. Calculation procedure of boron hardenability factors for the melts 7 and 8 .

\begin{tabular}{|c|}
\hline $\begin{array}{l}\text { ASTM Grain size GS of the melt } 7: \\
\text { GS }=16.54-2.88 \times \ln (10.88) \\
\text { GS }=9.67 \\
\text { ASTM Grain size GS of the melt } 8: \\
\text { GS }=16.54-2.88 \times \ln (8.50) \\
\text { GS }=10.38\end{array}$ \\
\hline $\begin{array}{l}\text { Ideal critical diameter } D_{I J} \text { of the melt } 7: \\
\qquad D_{I J}=100.6 \mathrm{~mm} \\
\text { Ideal critical diameter } D_{I J} \text { of the melt } 8 \text { : } \\
\qquad D_{I J}=154.1 \mathrm{~mm}\end{array}$ \\
\hline $\begin{array}{c}\text { Correction factor } f_{\text {corr }} \text { for the melt } 7: \\
f_{\text {corr }}=6.4217+3.78 \times 10^{-3} \times 810-0.2964 \times 810^{2} \\
f_{\text {corr }}=-194459 \\
\text { Correction factor } f_{\text {corr }} \text { for the melt } 8: \\
f_{\text {corr }}=6.4217+3.78 \times 10^{-3} \times 890-0.2964 \times 890^{2} \\
f_{\text {corr }}=-234769\end{array}$ \\
\hline $\begin{array}{l}\text { Corrected distance of semi-martensitic zone } J_{c} \text { for the melt 7: } \\
\qquad \begin{array}{c}J_{c}=20.0 \times \frac{-234769}{-194459} \\
J_{c}=24.2 \mathrm{~mm}\end{array}\end{array}$ \\
\hline $\begin{array}{l}\text { Corrected critical diameter } D_{I J c} \text { of the melt 7: } \\
\qquad D_{I J c}=112.7 \mathrm{~mm}\end{array}$ \\
\hline $\begin{array}{c}\text { Corrected critical diameter } D_{\text {IJccorr }} \text { of the melt } 7: \\
D_{\text {IJcorr }}=112.7 \times \frac{11.502169 \times 3.157685 \times 1.147922 \times 1.035002 \times 2.130000 \times 1.044094}{12.945274 \cdot \times 3.034934 \times 1.147922 \times 1.036230 \times 1.974884 \times 1.039278} \\
D_{\text {IJcorr }}=112.8 \mathrm{~mm}\end{array}$ \\
\hline $\begin{array}{l}\text { Factor } f_{2}: \\
f_{2}=\frac{112.8}{154.1} \\
f_{2}=0.73\end{array}$ \\
\hline
\end{tabular}

Table 9. Hardenability parameters of the melts 1 and 2.

\begin{tabular}{ccccccccc}
\hline No. of Melt & HRC $_{50}$ & $J(\mathbf{m m})$ & $D_{I J}(\mathbf{m m})$ & $J_{c}(\mathbf{m m})$ & $D_{I J c}(\mathbf{m m})$ & $\begin{array}{c}D_{I J c o r r} \\
(\mathbf{m m})\end{array}$ & $\begin{array}{c}D_{I}(\text { Calculated by the } \\
\text { Grossmann's Method) (mm) }\end{array}$ & $\begin{array}{c}f_{2}(B a s i c \\
\text { Melt 2) }\end{array}$ \\
\hline Melt 1 & 38.0 & 1.7 & 13.5 & 1.6 & 12.8 & 16.3 & 19.3 & 1.04 \\
Melt 2 & 40.0 & 2.0 & 15.7 & - & - & - & - \\
\hline
\end{tabular}

Table 10. Hardenability parameters of the melts 3 and 4 .

\begin{tabular}{ccccccccc}
\hline No. of Melt & HRC $_{50}$ & $J(\mathbf{m m})$ & $D_{I J}(\mathbf{m m})$ & $J_{c}(\mathbf{m m})$ & $D_{I J c}(\mathbf{m m})$ & $\begin{array}{c}D_{I J c o r r} \\
(\mathbf{m m})\end{array}$ & $\begin{array}{c}D_{I}(\text { Calculated by the } \\
\text { Brossmann's Method) }(\mathbf{m m})\end{array}$ & $\begin{array}{c}f_{2}(\text { Basic } \\
\text { Melt 4) }\end{array}$ \\
\hline Melt 3 & 43.0 & 27.5 & 122.4 & 28.2 & 122.9 & 104.4 & 93.2 & 0.91 \\
Melt 4 & 41.0 & 25.0 & 114.9 & - & - & - & 82.9 & - \\
\hline
\end{tabular}

Table 11. Hardenability parameters of the melts 5 and 6 .

\begin{tabular}{|c|c|c|c|c|c|c|c|c|}
\hline No. of Melt & HRC $_{50}$ & $J(\mathrm{~mm})$ & $D_{I J}(\mathrm{~mm})$ & $J_{c}(\mathrm{~mm})$ & $D_{I J c}(\mathrm{~mm})$ & $\begin{array}{l}D_{\text {IJcorr }} \\
(\mathrm{mm})\end{array}$ & $\begin{array}{c}D_{I}(\text { Calculated by the } \\
\text { Grossmann's Method) (mm) }\end{array}$ & $\begin{array}{l}f_{2}(\text { Basic } \\
\text { Melt 6) }\end{array}$ \\
\hline Melt 5 & 42.0 & 35.0 & 137.1 & 37.5 & 141.9 & 141.6 & 94.5 & 1.26 \\
\hline Melt 6 & 41.0 & 23.5 & 112.1 & - & - & - & 94.3 & - \\
\hline
\end{tabular}

Table 12. Hardenability parameters of the melts 7 and 8 .

\begin{tabular}{ccccccccc}
\hline No. of Melt & HRC $_{50}$ & $J(\mathbf{m m})$ & $D_{I J}(\mathbf{m m})$ & $J_{c}(\mathbf{m m})$ & $D_{I J c}(\mathbf{m m})$ & $\begin{array}{c}D_{\text {Ijcorr }} \\
(\mathbf{m m})\end{array}$ & $\begin{array}{c}D_{I} \text { (Calculated by the } \\
\text { Grossmann's Method) (mm) }\end{array}$ & $\begin{array}{c}f_{2}(\text { Basic } \\
\text { Melt 8) }\end{array}$ \\
\hline Melt 7 & 42.0 & 20.0 & 100.6 & 24.2 & 112.7 & 112.8 & 108.3 \\
Melt 8 & 37.0 & 45.0 & 154.1 & - & - & - & 0.73 \\
\hline
\end{tabular}




\section{Conclusions}

The purpose of this work was to evaluate the effect of boron on hardenability of steel quantitatively and to assess this effect in the case when boron is applied together with other alloying elements like chromium, vanadium and titanium. During the analysis, the ideal critical diameter was made independent of austenitization temperature, grain size and chemical composition, so it was possible to investigate the effect of boron as the hardenability intensifier. On the basis of the research carried out, it can be concluded that the effect of boron on hardenability of the non-alloyed steel was negligible. For melt 1 the factor $f_{2}$ was equal to 1.04 . Introduction of ca. $1 \%$ of chromium and ca. $1.30 \%$ of manganese did not cause any hardenability increase resulting from action of boron. For melt 3 the factor $f_{2}$ was equal to 0.91 . It is only a complex introduction of manganese, chromium and vanadium that improved the effect of boron as the hardenability intensifier. For melt 5 the factor $f_{2}$ was equal to 1.26 so the presence of microadditivites such as vanadium and boron can even increase hardenability by about $26 \%$. Insufficient quantity of other microadditives resulted in a loss of advantages caused by the action of boron as the element improving hardenability and could even result in a decrease of hardenability of the boron-containing steel. This is particularly evident in melt 7 , where the titanium content was insufficient to counteract the binding of boron in boron nitrides, which lost the positive effect of boron on hardenability.

The author's interest also lied in the complex analysis of the influence of chromium, vanadium and titanium in the presence of boron on the structure morphology and grain size of analyzed low-alloy cast steels. The smallest grain size was obtained for melt 6 after austenitizing at $870{ }^{\circ} \mathrm{C}$ and the largest grain size for melt 1 , after austenitizing at $890^{\circ} \mathrm{C}$. In melt 1, large abnormal grains appeared just after austenitizing at $890^{\circ} \mathrm{C}$. After normalizing, the melts containing chromium, vanadium and titanium underwent partial quenching, revealing the whole spectrum of hardening structures, such as martensite, troostite and sorbite. After quenching, the martensitic structures of the melts containing chromium, vanadium and titanium were similar to one another. Melt 1 was characterized by a thick needle-shaped martensite structure with precipitates at grain boundaries in upper bainite. In melt 2 martensite was finer, however, it was still possible to observe acicular ferrite against its background. Simultaneously, the melts containing boron gained higher hardness than the melts with similar chemical composition but without boron.

Due to the fact that the summary effect of alloy additions may be hard to predict or calculate and data usually presents the influence of individual elements on the position of the critical temperatures of phase changes and points in the iron-cementite diagram, future research will focus on the influence of boron in the presence of other elements like chromium, molybdenum, manganese and niobium on the transformations occurring during continuous cooling, on the morphology of carbide and nitride phase precipitates. What is more, the mechanism of toughness improvement or degradation by boron addition in heat-treatable steels remains to be unambiguously identified so the influence of boron to the resistance to dynamic loads, together with the influence on the morphology of the obtained fractures will be analyzed. However, since most boron steels are intended for machine working elements exposed to abrasive wear, an analysis of the effects on abrasive wear resistance and wear mechanisms will be carried out. Therefore, the scientific considerations indicated in the study seem to be most justified. In addition, the author is of the opinion that it is not possible to carry out extended research on the influence of boron, for example, in the field of fracture mechanics, without determining the actual structuralstrength characteristics obtained in the course of basic research and fractographic analysis. The planned research, together with the effect of boron on hardenability in the presence of other alloying and micro-alloying elements presented in the manuscript, will allow a comprehensive assessment of the influence of this element on a number of structural and mechanical properties of steels, which will make it possible to rationally approach the use of the potential of this element in the design of new structural steels, and a rational approach to structural and material solutions for selected machine elements, based on 
actual research results, which may significantly extend the service life or even extend the operational capabilities of the entire work object in which such materials will be used. Examples of such planned and well-executed research experiments, the results of which have significantly influenced the optimization of technological processes and material properties, resulting in the durability of the entire structure, can be found in such works as [35-37].

Funding: This study was funded by grand number 0402/0075/18.

Institutional Review Board Statement: Not applicable.

Informed Consent Statement: Not applicable.

Data Availability Statement: Not applicable.

Conflicts of Interest: The author declares no conflict of interest.

\section{References}

1. SSAB-Oxelösund. Hardox_Das Verschleißblech der Vielen Möglichkeiten; Information Materials of Ironworks SSAB-Oxelösund; SSAB: Oxelösund, Sweden, 2002.

2. Bin Khiyon, M.R.; Salleh, S.M. Effect of heat-treatment on the hardness and mechanical properties of boron alloyed steel. MATEC Web Conf. 2017, 90, 12. [CrossRef]

3. Geiger, M.; Duflou, J.; Kals, H.J.J.; Shirvani, B.; Singh, U.P. Basic investigations on the hot stamping steel 22MnB5. Adv. Mater. Res. 2005, 6, 795-804. [CrossRef]

4. Güler Özgül, H.; Ertan, R.; Ozcan, R. Influence of heat treatment parameters on the microstructure and mechanical properties of boron-alloyed steels. Mater. Test. 2012, 54, 1-6. [CrossRef]

5. Venturatoa, G.; Novellaa, M.; Bruschia, S.; Ghiottia, A.; Shivpuri, R. Effects of phase transformation in hot stamping of 22MnB5 high strength steel. Procedia Eng. 2017, 183, 316-321. [CrossRef]

6. Białobrzeska, B.; Jasiński, R.; Konat, Ł.; Szczepański, Ł. Analysis of the properties of hardox extreme steel and possibilities of its applications in machinery. Metals 2021, 11, 162. [CrossRef]

7. Yoon-Suk, C.; Sung-Joon, K.; Ik-Min, P.; Kwang-Woo, K.; In-Suk, Y. Boron distribution in a low-alloy steel. Met. Mater. 1997, 3, 118-124.

8. Maitrepierre, P.; Thivellier, D.; Rofes-Vernis, J.; Rousseau, D.; Tricot, R. Hardenability Concepts with Applications to Steel; Doane, D.V., Kirkaldy, J.S., Eds.; AIME: Englewood, CO, USA, 1978; pp. 421-447.

9. Llewellyn, W.T.; Cook, W.T. Heat treatment distortion in case carburising steels. Met. Technol. 1977, 4, 265-278. [CrossRef]

10. Kapadia, B.M.; Brown, R.M.; Murphy, W.J. The influence of nitrogen, titanium and zirconium on the boron hardenability effect in constructional steels. Trans. Met. Soc. AIME 1968, 242, 1689-1694.

11. Melloy, G.F.; Slimmon, P.R.; Podgursky, P. Segregation and the strength of grain boundaries. Met. Transit. 1973, 4, 2279-2289. [CrossRef]

12. Sharma, M.; Ortlepp, I.; Bleck, W. Boron in heat-treatable steels: A review. Steel Res. Int. 2019, 90, 1-28. [CrossRef]

13. Grimm, W. Technischer Bericht; Edelstahlwerke Buderus AG: Wetzlar, Germany, 1980.

14. Yamanaka, K.; Ohmori, Y. Effect of boron on transformation of low-carbon low-al loy steels. Tetsu-to-Hagane 1976, 62, 895-904. [CrossRef]

15. Asahi, H. Effects of mo addition and austenitizing temperature on hardenability of low alloy b-added steels. ISIJ Int. 2002, 42, 1150-1155. [CrossRef]

16. Opiela, M. Structure and mechanical properties of forged microalloyed steel products manufactured with the thermo-mechanical treatment. Hutnik 2013, 80, 579-583.

17. Taylor, K.A. Grain-boundary segregation and precipitation of boron in 0.2 percent carbon steels. Metall. Mater. Trans. A 1992, 23, 107-119. [CrossRef]

18. Dobrzański, L.A. Basics of Materials and Metals Science; WNT Scientific and Technical Publishing House: Warsaw, Poland, 2013. (In Polish)

19. Ueno, M.; Itoh, K. New empirical formula for estimation of hardenability from chemical compositions. ISIJ Int. 1988, 74, 1073-1080.

20. Pickering, F.B. Physical Metallurgy and the Design of Steels; Applied Science Publishers Ltd: London, UK, 1978.

21. Titova, T.I.; Shulgan, N.A.; Malykhina, I.Y. Effect of boron microalloying on the structure and hardenability of building steel. Met. Sci. Heat Treat. 2007, 49, 39-44. [CrossRef]

22. Kupczyk, J.; Lis, A.K. Influence of boron on kinetics of phase transformations in steel 1021. In Proceedings of the 12th International Scientific Conference Achievements in Mechanical and Materials Engineering, Gliwice, Poland, 7-10 December 2003; pp. 547-550. (In Polish).

23. Totten, G.E. Steel Heat Treatment: Metallurgy and Technologies Handbook; Portland State University: Portland, OR, USA, 2007. 
24. Briedis, J.B.; Cuddy, L.J. Enhanced hardenability in microalloyed steels. Key Eng. Mater. 1993, 84, 157-192. [CrossRef]

25. Naderi, M.; Ketabchi, M.; Abbasi, M.; Bleck, W. Analysis of microstructure and mechanical properties of different boron and non-boron alloyed steel after being hot stamped. Procedia Eng. 2011, 10, 460-465. [CrossRef]

26. Grange, R.A.; Mitchell, J.B. On the hardenability effect of boron in steel. Trans. Am. Soc. Met. 1961, 53, 157-185.

27. Hodge, J.H.; Orehoski, M.A. Relationship between hardenability and percentage of martensite in some alloy steels. Trans. Am. Soc. Met. 1946, 167, 627-642.

28. Grossmann, H.A. Elements of Hardenability; ASM: Metals Park, OH, USA, 1952.

29. Garbarz, B.; Pickering, F.B. Effect of vanadium and austenitising temperature on hardenability of $(0.2-0.3) \mathrm{C}-1,6 \mathrm{Mn}$ steels with and without addition of titanium, aluminium and molybdenum. Mater. Sci. Technol. 1988, 4, 114-126. [CrossRef]

30. Adrian, H. A Mechanism for effect of vanadium on hardenability of medium carbon manganese steel. Mater. Sci. Technol. 1999, 15, 366-378. [CrossRef]

31. Pelczar, M. The Influence of Micro-Additives on the Hardenability of Steel with Boron. Ph.D. Thesis, University of Science and Technology, Krakow, Poland, 2010. (In Polish).

32. Jackson, C.E.; Christenson, A.L. The effect of quenching temperature on the results of the end-quench hardenability test. Trans. Am. Soc. Met. 1944, 158, 125-137.

33. Moser, A.; Legat, A. Die berechnung der härtbarkeit aus der chemischen zusammensetzung. Härt. Tech. Mitt. 1969, 24, 100-105.

34. Nakasato, F; Takahashi, M. Effects of boron, titanium, and nitrogen on the hardenability of boron-treated steels for heavy machinery. Met. Technol. 1979, 6, 102-105. [CrossRef]

35. Erdakova, N.; Tkachevb, V.M.; Novokreshchenova, V.V. Increase of wear resistance of steel plates for crushing stations. J. Frict. Wear 2014, 35, 514-519. [CrossRef]

36. Juez-Gil, M.; Nikolaevich Erdakov, I.; Bustillo, A.; Yurievich Pimenov, D. A regression-tree multilayer-perceptron hybrid strategy for the prediction of ore crushing-plate lifetimes. J. Adv. Res. 2019, 18, 173-184. [CrossRef]

37. Fernández, B.; González, B.; Artola, G.; López de Lacalle, N.; Angulo, C. A quick cycle time sensitivity analysis of boron steel hot stamping. Metals 2019, 9, 235. [CrossRef] 